\title{
Quality evaluation of prawn crackers produced from blends of prawns and cassava (Manihot esculenta), pink and orange fleshed sweet potato (Ipomoea batatas (L) Lam) starches
}

\author{
${ }^{*}$ Mbaeyi-Nwaoha, I.E. and Itoje, C.R. \\ Department of Food Science and Technology, University of Nigeria, Nsukka (www.unn.edu.ng) \\ *Corresponding author Email: miphie2003@yahoo.co.uk or ifeoma.mbaeyi-nwaoha@unn.edu.ng
}

\begin{abstract}
Prawn crackers produced for cassava starch (CAS), pink (PPS) and orange (OPS) fleshed sweet potato were investigated. Nine samples were produced using varying proportions (100\%, 90:10\%, and 80:20\%) of prawn and starch. Prawn crackers were formulated by mixing, steaming and refrigeration, sliced into small pieces and then dried in an oven at $40{ }^{\circ} \mathrm{C}$. The sliced, dried products were then stored for one month and analyzed in a week interval. This study analyzed some selected functional properties (water absorption capacity (WAC), oil absorption capacity (OAC), bulk density (BD), swelling capacity (SC), particle size distribution (PS) and viscosity of the starches obtained from cassava, pink and orange fleshed sweet potato. Proximate composition, vitamins, minerals, antinutritional factors, $\mathrm{pH}$ and sensory evaluation were determined. Mould count was determined during one month storage. The results revealed that the starch had WAC (1.85\% for OPS, $2.10 \%$ for PPS and $2.19 \%$ for CAS; OAC $(1.85 \%$ for OPS, $1.94 \%$ for PPS and $2.04 \%$ for CAS); BD $(68.96 \mathrm{~g} / \mathrm{ml}$ for OPS, $69.26 \%$ for PPS and $72.44 \mathrm{~g} / \mathrm{ml}$ for CAS); SC (5.60\% for OPS, $5.35 \%$ for PPS, and $5.75 \%$ CAS). For viscosity, the peak viscosities had the maximum viscosity developed during or soon after the heating portion (141.75 RVU for OPS, 274.17 RVU for PPS and $168.92 \mathrm{RVU}$ for CAS), pasting temperature $\left(82.55^{\circ} \mathrm{C}\right.$ for PPS, $83.66{ }^{\circ} \mathrm{C}$ for OPS and $84.18{ }^{\circ} \mathrm{C}$ for CAS), the gelatinization temperature $\left(64.5{ }^{\circ} \mathrm{C}\right.$ for PPS and $74.0^{\circ} \mathrm{C}$ for CAS), breakdown viscosity (29.42 RVU for OPS 40.17 RVU for PPS and 179.84 RVU for CAS), final viscosity (131.58 RVU for PPS, 165 RVU for OPS and 207.17 RVU for CAS), setback viscosity (37.25 RVU for PPS and 78.42 RVU for CAS). Moisture (2.41 - 5.63\%), protein (2.68 - 19.64\%), fat (3.71 - 13.62\%), carbohydrate (56.48 - 87.34\%), ash $(0.07-4.24 \%)$, crude fibre $(0.56-3.43 \%)$ and $\mathrm{pH}(5.46-8.23)$ were obtained. For Vitamins $A(113-128$ $\mathrm{mg} / 100 \mathrm{~g})$, B1 (0.05 - $0.07 \mathrm{mg} / 100 \mathrm{~g})$, B3 (0.04 - $0.87 \mathrm{mg} / 100 \mathrm{~g})$, B6 (0.09 - $0.71 \mathrm{mg} / 100 \mathrm{~g})$, B12 (0.0019 $0.0038 \mathrm{mg} / 100 \mathrm{~g}), C(0.00-1.02 \mathrm{mg} / 100 \mathrm{~g}), \mathrm{D}(0.01-0.19 \mathrm{mg} / 100 \mathrm{~g}), \mathrm{E}(0.15-0.38 \mathrm{mg} / 100 \mathrm{~g})$. Mineral content were $\mathrm{Na}$ (13.51 - $117 \mathrm{mg} / 100 \mathrm{~g})$, Ca (15.56 - $29.92 \mathrm{mg} / 100 \mathrm{~g}), \mathrm{Zn}(0.15-0.44 \mathrm{mg} / 100 \mathrm{~g}), \mathrm{Fe}(0.22-0.71 \mathrm{mg} / 100$ g), Cu (0.11 - $0.48 \mathrm{mg} / 100 \mathrm{~g})$, Mg (20.84 - $23.58 \mathrm{mg} / 100 \mathrm{~g})$, Se (0.61 - $4.77 \mathrm{mg} / 100 \mathrm{~g})$. During storage, mould growth was observed at week three with CSC (90:10), OPC (80:20), and OPC (90:10).
\end{abstract}

Key words: Cassava starch, Pink and orange fleshed sweet potato, Prawn crackers and Prawn

\section{INTRODUCTION}

Prawn cracker is a traditional means of extending the shelf life of prawns or shrimps (shell fish) used by foreign countries such as Malaysia and Australia (Cheow and $\mathrm{Yu}, 1997)$. Nowadays, the product is becoming popular in Nigeria, particularly urban centres. The product is available in general stores, drinking bars and in general supermarkets (Parkinson, 2006). It is available as fried and unfried crackers may be coloured or transparent and they are stored in low humidity environment or in an airtight container to preserve its crispness (Anon., 2012a).

Prawn cracker is produced by mixing prawns, food starch, salt, sugar, monosodium glutamate (MSG) and oil for frying. Other ingredients maybe added depending on the producer's choice (Parkinson, 2006). The ingredients (after cleaning) are mixed, steamed/boiled, refrigerated, 
sliced into small piece and then sun-dried first before frying, until the moisture content reaches around 10 percent (Huda et al., 2007). The sliced, dried product is fried in cooking oil. In only a second, the products expand into thumb -sized semi-transparent chips to white fluffy crackers more like popcorn, with the water bound to the starch expands as it turns into steam. If left in the open air for more than few hours (depending on humidity), they start to soften and become chewy and therefore are ideally consumed within a few hour of being fried (Anon., 2012b).

In recent times, kneading machine, pressure pot, extruder and a dehydrator are used in the production of prawn crackers (Hiu, 2012). Traditionally, the cut slices are placed on trays or strainer and sun-dried. At intervals, the cut slices are turned to avoid sticking and for effective drying (Parkinson, 2006). There are five main stages in the processing of prawn cracker. In the first stage, the ingredients are prepared and mixed (blended) to form dough, the second stage involves the steaming / boiling of the dough in a pressure pot and allowed to cool in a refrigerator. The third stage involves the slicing into thin pieces and fourthly, the drying process using sun or a dehydrator and lastly, the dried thin slices are deep fried (Parkinson, 2006).

Prawn cracker is gradually receiving a worldwide acceptability (Parkinson, 2006). It is an irresistible snack for children and adult alike and it goes well with beer. The product is enjoyed in Nigeria and internationally in cocktail parties, various ceremonies such as in birthday parties and can also be used as a welcome package as well as take-away. According to Anon. (2012a), processing of prawn crackers has being modernized using a dehydrator-microwave oven. Although the processing is fast, it causes the product to cook and expand in a way similar to when they are deep fried. However the sun-dried products are preferred but it stands the risk of attracting dust/dirts and being attacked by local wildlife such as cats and others from sampling the product (Hiu, 2012). The product is of foreign origin and it is being imported to Nigeria. However, there are many food starches that could be used in the production of prawn cracker and they include wheat, maize (corn), rice, sago, rice and even mung bean are available for prawn cracker making (Seth and Rao, 2008). It is possible to use starch obtained from cassava and sweet potatoes in the production of prawn cracker but no work has been carried out to investigate this in Nigeria. Although in the South Eastern Nigeria, some researchers have tried to assess cassava crackers (a third generation snack) using protein sources according to Obasi and Chukwuma (2015). Many types of proteins and protein enrichment may be added to third generation snack type recipes such as meats (whole fresh shrimp, fresh chicken, beef, etc.), dairy products (cheese, yoghurt, milk solids) and legume proteins (soy, pea, bean).
Therefore, the main aim of this work was to investigate the performance of the starch obtained from cassava, pink and orange fleshed sweet potato in the production of prawn cracker and ascertain the functional properties, microbiological count and sensory acceptability of the product as well as to determine the storage stability of the product.

\section{MATERIALS AND METHODS}

\section{Procurement of Raw Materials}

Fresh prawn (Penaeus monodon) was purchased from Sansan market in Warri, Delta State. Orange fleshed sweet potato were purchased from National Root Crops Research Institute (NRCRI) Umudike, Abia State. Pink fleshed sweet potato and other ingredients such as salt, monosodium (MSG) were purchased from Ogige main market, Nsukka, Enugu State.

\section{Sample Preparation}

\section{Processing of Starch}

Cassava, pink and orange fleshed sweet potatoes were cleaned for removal of soil and stones manually with the aid of water and sponge. The materials were peeled with sharp knife to remove the skin cortex covering the potato and then rinsed with water. Then the cleaned cassava and potatoes were grated for complete disruption of the cells, thereby releasing the starch. The milled cassava and potato slurries were then washed with the aid of sieves and water was used for thorough washing. The starch and filtrate passed through and the fibres were retarded by the sieves. The remaining pulp was drained or pressed off and used directly as feed while damp or dried. The filtrate was seperated from the starch (residue) with the aid of a muslin cloth. The starch was then deried in a hot air oven to a moisture content not exceeding 15 $2 \%$ of residual moisture to be suitable for storage according to Strasse (2012) as shown in (Figure 1).

\section{Processing of Prawn Stock}

The wastes (shell, tails and legs) were removed from the prawns and boiled to extract the stock and then used in the mixing process (Figure 1).

\section{Processing of the Prawn Cracker}

The prawn meat was deveined, the legs removed and boiled to extract the prawn stock. The prawn cracker was prepared using following the unit operations (Figure 2). 
068 Afr. J. Food Sci. Technol.

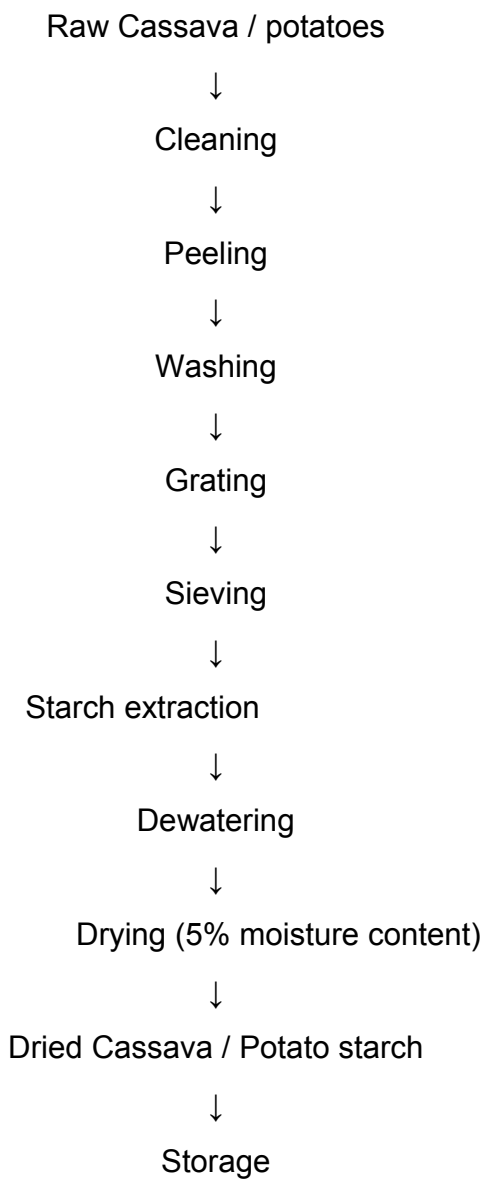

Figure 1. Preparation of cassava, pink and Orange fleshed sweet potato starches Source: Strasse (2012)

Proportions of blending prawn meat and starch (from cassava, pink and orange fleshed sweet potatoes) Table 1 shows the proportions for the blending of prawn meat and starch (from cassava, pink and orange fleshed sweet potatoes).

\section{Functional properties}

\section{Determination of Bulk density}

Bulk density was determined using the method described by Onimawo and Egbekun (1998). About $20 \mathrm{~g}$ of each sample starch was placed into a $100 \mathrm{ml}$ graduated cylinder was tapped gently about 10 times against the palm and the final volume was expressed in $\mathrm{g} / \mathrm{dl}$. All analysis was in duplicate.

\section{Determination of pasting characteristics}

The pasting profile was studied using a Rapid Visco Analyzer (RVA) series 4 as described by Newport Scientific Incorporated (1998). Three grams of sample was weighed and $25 \mathrm{ml}$ of distilled water was dispensed into a canister. A paddle was placed inside the canister; and then inserted into the RVA machine. The measurement cycle was initiated by pressing the motor regulator of the instrument. The profile was taken as it runs in the monitor of the computer connected to the instrument. A 12 minute profile was used, the timetemperature regime used was temperature $50{ }^{\circ} \mathrm{C}$ for 1 min, heated from $50-95{ }^{\circ} \mathrm{C}$ in 3 min $45 \mathrm{~s}$, then held at $95{ }^{\circ} \mathrm{C}$ for $2 \min 30 \mathrm{~s}$, the sample was subsequently cooled to $50{ }^{\circ} \mathrm{C}$ over a $3 \min 45 \mathrm{~s}$ period followed by a period of 2 min where the temperature was controlled at $50{ }^{\circ} \mathrm{C}$.

\section{Particle size distribution}

The particle size was determined by the method described by lhekoronye and Oladunjoye (1988). A nest of 12 sieves (BS $5,8,10,12,22,30,44,60,85,120$, 150 , and 170 mesh screens) corresponding to sieve openings (2) was arranged in order. The upper sieve was provided with a cover and the bottom sieve was provided with a receiver. A $50 \mathrm{~g}$ sample of the product was put in the top sieve, covered with the lid and the nest of sieves placed in a suitable mechanical sieve shaker (Endecott test sieve shaker, Britain). The material was stopped, the nest removed and the residue on each sieve continuously for 5 min after which sieving was stopped, the nest 
Nwaoha and Itoje, 069

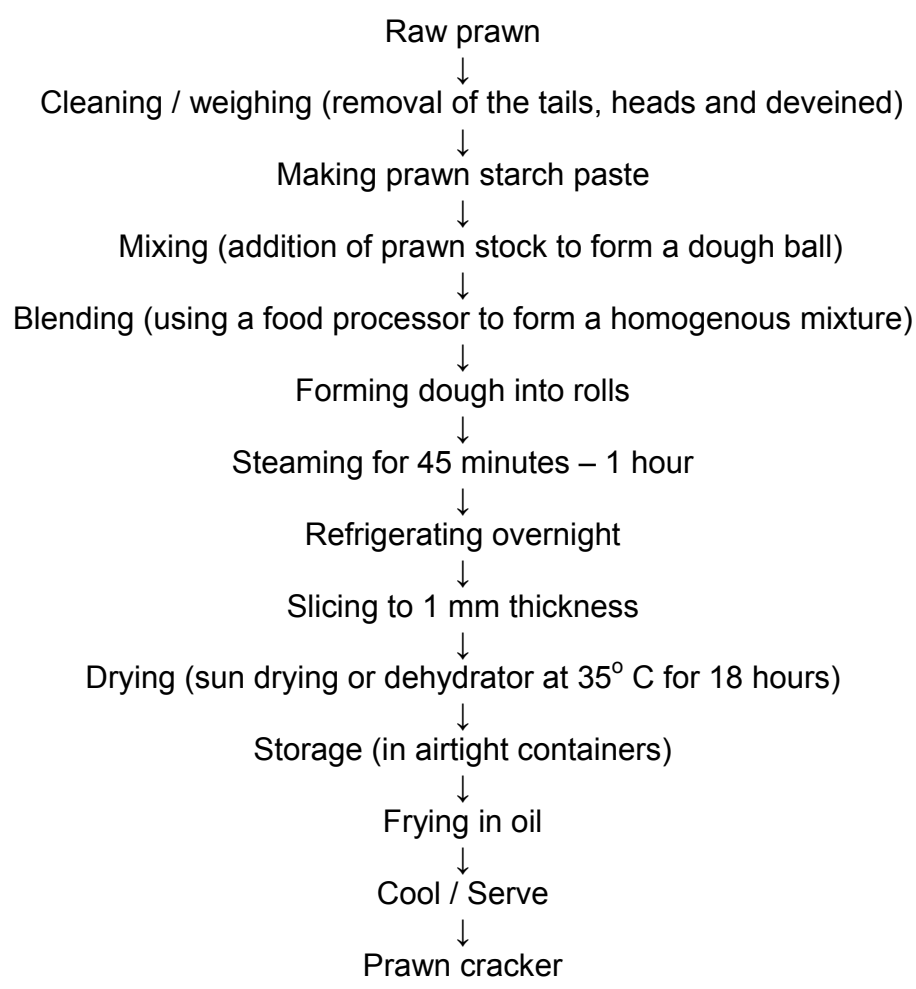

Figure 2. Production of prawn cracker

Source: Parkinson (2006)

removed and the residue on each sieve transferred to a tarred weighing dish using a brush. Each dish was weighed and the percentage of the product retained on each sieve was calculated.

\section{Oil absorption capacity}

The oil absorption capacity was determined by the method of Beuchat (1977). One gram of each sample was mixed with $10 \mathrm{ml}$ of edible vegetable oil for $30 \mathrm{sec}$ in a mixer (super mixer cat No. 1291 Labeline instruments Inc, USA). Samples were allowed to stand at room temperature $\left(25 \pm 1^{\circ} \mathrm{C}\right)$ for $30 \mathrm{~min}$ and the volume of the supernatant noted in a $10 \mathrm{ml}$ graduated cylinder. Density of oil was assumed to be $0.38 \mathrm{~g} / \mathrm{dm}$ and the result was expressed on dry weight basis. The determinations of density of the samples were calculated as the ratio of mass to volume. The difference in densities gives the oil absorption capacity of the samples.

\section{Water absorption capacity}

The water absorption capacity was determined by the method of Beuchat (1977). One gram of each sample was mixed with distilled water for $30 \mathrm{sec}$ in a mixer (super mixer cat No.1291, Labeline Instrument Inc, USA). The samples were then allowed to stand at room temperature $\left(25{ }^{\circ} \mathrm{C}\right)$ for $30 \mathrm{mins}$, centrifuged at $500 \mathrm{rpm}$ for $30 \mathrm{~min}$ and the volume of the supernatant noted in a $10 \mathrm{ml}$ graduated cylinder. Density of water was assumed to be $1.0 \mathrm{~g} / \mathrm{ml}$ to volume and the results were expressed on dry weight basis after the determination of the density of the sample (ratio of the mass to volume). The difference of the densities gives the water absorption capacity of samples.

\section{Swelling power and solubility}

The swelling power and solubility was determined by the method of Tester and Morrison (1990). One gram of samples accurately weighed and quantitatively transferred into a clear dried test tube and re-weighed $\left(w_{1}\right)$. The flour/starch was then dispersed in $50 \mathrm{~cm}^{3}$ of distilled water using a mixer. The resultant slurry was heated at the desired temperature $\left(65,75,85\right.$ and $\left.95^{\circ} \mathrm{C}\right)$ for $30 \mathrm{~min}$ in a water bath. The mixture was cooled to $28 \pm 2{ }^{\circ} \mathrm{C}$ and centrifuged at $2200 \mathrm{rpm}$ for $15 \mathrm{~min}$ to separate the gel and supernatant. Then, the aqueous supernatant was removed and poured into dish for subsequent analysis of solubility pattern. After this, the weight of the swollen sediment was determined $\left(w_{2}\right)$. The supernatant liquid $(5 \mathrm{ml})$ was poured into a tarred evaporating dish and dried to a constant weighed in air oven at $100{ }^{\circ} \mathrm{C}$ for $4 \mathrm{~h}$. Water solubility index was determined from the amount of dried solids obtained after 
drying the supernatant and was expressed as gram dried solids per gram of sample.

Solubility $(\%)=W_{1} \times 100 / \mathrm{Ws}(1-\mathrm{Mc})$

Swelling power $(\%)=W_{2} \times 100 / W d m(100$ - solubility $)$

Dry matter weight $=\mathrm{Ws}(1-\mathrm{MC})$

Where,

$W_{1}, W_{2}=$ Weight of supernatant and centrifuged swollen granules; $\mathrm{Ws}=$ weight of sample; $\mathrm{Mc}=$ moisture content of sample, Dry basis (decimal); $\mathrm{W}_{\mathrm{dm}}=$ weight of dry matter.

\section{Proximate analyses}

\section{Determination of moisture content}

Moisture content was determined by hot air oven method as described by AOAC (2010). Cleaned crucibles were dried in the oven at $100{ }^{\circ} \mathrm{C}$ for $1 \mathrm{hr}$ to obtain a constant weight $\left(w_{1}\right)$ and then cooled in the desiccator $\left(w_{2}\right)$. Two grams of the sample was weighed into the crucible and dried at $105^{\circ} \mathrm{C}$ until a constant weight was obtained $\left(w_{3}\right)$. Moisture content was calculated as follows;

$\%$ Moisture content $=\left(w_{2}-w_{3}\right) /\left(w_{2}-w_{1}\right) \times 100$

Where: $W_{1}=$ initial weight of empty crucible; $W_{2}=$ weight of dish + sample before drying; $W_{3}=$ weight of dish + sample after drying.

\section{Determination ash content}

The ash content was determined using AOAC (2010) procedure. Then, $2 \mathrm{~g}$ of finely ground sample was weighed $\left(w_{1}\right)$ into a preheated cooled crucible. This sample was charred on a Bunsen flame inside a fume cupboard $\left(w_{2}\right)$. The sample was transferred into a preheated muffle furnace at $550{ }^{\circ} \mathrm{C}$ for $3 \mathrm{hrs}$ until a white or light grey ash was obtained. It was cooled in a desiccator and weighed $\left(w_{3}\right)$. The ash content was calculated as follows;

$\%$ Ash content $=\left(w_{2}-w_{3}\right) /\left(w_{2}-w_{1}\right) \times 100$

Where: $W_{1}=$ weight of empty crucible; $W_{2}=$ weight of crucible + sample before ashing; $W_{3}=$ weight of crucible + ash (sample after ashing).

\section{Determination of crude protein content}

The crude protein content was determined as described by AOAC (2010) using micro-Kjeldahl method. Two grams of sample was weighed into Kjeldahl flask. Ten milliliters of concentrated $\mathrm{H}_{2} \mathrm{SO}_{4}$ and five grams of anhydrous sodium sulphate was added. It was heated in the fume chamber until solution became clear. The solution was cooled to room temperature after which it was transferred into a $100 \mathrm{ml}$ volumetric flask and made up to the level with distilled water.
The distillation unit was cleaned and the apparatus was set up. A $100 \mathrm{ml}$ conical flask, (receiving flask) containing $5 \mathrm{ml}$ of boric acid and drops of methyl red indicator was placed under the condenser. Five milliliters $(5 \mathrm{ml})$ of the digest was pipette into the apparatus through the small funnel and washed down with distilled water and followed by addition of $5 \mathrm{ml}$ of $60 \% \mathrm{NaOH}$ solution. The distillate was collected in the receiving flask. The distillate in the receiving flask was titrated with $0.049 \mathrm{M} \mathrm{H}_{2} \mathrm{SO}_{4}$ to a pink colour. The same procedure was carried out on the blank (with filter paper).

$\%$ Protein $=($ Titre - Blank $) \times 0.00014 \times$ dilution factor $\mathrm{x}$ $6.25 \times 100$

Weight of sample

\section{Determination of fat content}

The Soxhlet extraction method of AOAC (2010) was used. A Soxhlet extractor with a reflux condenses and a $500 \mathrm{ml}$ round between flasks is fixed. About $2 \mathrm{~g}$ sample was weighed into a labelled thimble. Petroleum ether $(300 \mathrm{ml})$ was filled into the round bottom flask. The extraction thimble was sealed with cotton wool. The Soxhlet apparatus was allowed to reflux for about $6 \mathrm{~h}$, the thimble was removed with care and petroleum ether collected at the top and drained into a container for reuse. When the flask is free of ether, it was removed and dried at $105^{\circ} \mathrm{C}$ for $1 \mathrm{hr}$ in an oven, cooled in desiccator and weighed.

$\%$ Fat $=\frac{\text { weight of fat }}{\text { Weight of sample }} \times 100$

\section{Determination of crude fiber content}

The crude fiber was determined according to the method of AOAC (2010) method. Petroleum ether was used to defat $2 \mathrm{~g}$ of sample. This was put in boiled $200 \mathrm{ml}$ of 1.25 $\% \mathrm{H}_{2} \mathrm{SO}_{4}$ and boiled for $30 \mathrm{~min}$. The solution was filtered through linen or muslin cloth on a fluted funnel. It was washed with boiling water until it is free of acid. The residue was returned into $200 \mathrm{ml}$ boiling $\mathrm{NaOH}$ and allowed to boil for $30 \mathrm{~min}$. It was further washed with $1 \%$ $\mathrm{HCl}$ boiling water, to free it of acid. The final residue was drained and transferred to a silica ash crucible (porcelain crucible), dried in oven to a constant weight and cooled.

$\%$ Crude fiber $=$ loss in weight after ignition $\times 100$

\section{Determination of carbohydrate content}

Carbohydrate content of the samples was determined by difference as described by AOAC (2010) using the equation below. 
$\%$ Carbohydrate $=100-(\%$ Moisture $+\%$ Ash $+\%$ Protein $+\%$ Crude fibre $+\%$ Crude fat)

\section{Determination of vitamin contents}

\section{Determination of vitamin A content}

The colorimetric method of AOAC (2010) method was adopted which measures the unstable colour at the absorbance of $620 \mathrm{~nm}$ that result from the reaction between vitamin $\mathrm{A}$ and $\mathrm{SbCl}_{3}$. Pyrogallol (an antioxidant) was added to $2 \mathrm{~g}$ sample prior to saponification with 200 $\mathrm{ml}$ alcohol $\mathrm{KOH}$. The saponification took place in water bath for 30 minutes. The solution was transferred to a separator funnel where water was added. The solution was extracted with 1.0 to $1.5 \mathrm{ml}$ of hexane. The extract was washed with water. The extract was filtered through filter paper containing $5 \mathrm{~g}$ anhydrous $\mathrm{Na}_{2} \mathrm{SO}_{4}$ into volume flask. The filter paper was rinsed with hexane and made up to the volume. The hexane was evaporated from the solution and blank. About $1 \mathrm{ml}$ chloroform and $\mathrm{SbCl}_{3}$ solution was added to the extract and blank. The reading of the solution and blank was taken from the colorimeter adjusted to zero absorbance or $100 \%$.

\section{Calculation}

Mg Vitamin $A=A 620_{m m} \times S I \times(v / w t)$

Where $A 620 \mathrm{~nm}$ - absorbance at $620 \mathrm{~nm}$; SI - Slope of standard curve (Vit. A conc)/A620 reading); V - Final volume in colorimeter tube; $\mathrm{Wt}$ - Weight of sample.

\section{Determination of Vitamin C content}

2, 6 dichlorophenol titrimetric method was used according to AOAC (2010) method.

Apparatus: Warring blender, Buchner funnel, vacuum pump, Whatman No. 1 filter paper, $50 \mathrm{ml}$ burette, retort stand.

Reagents: Metaphosphoric acid, acetic acid, ascorbic acid standard $(1 \mathrm{mg} / \mathrm{ml}), 2,6$-dichloroindophenol sodium salt (Eastman Kodak Co. No. 3463), sodium bicarbonate.

Standardization of the method: A $50 \mathrm{mg} \mathrm{2,} \mathrm{6-}$ dichloroindophenol sodium salt was dissolved in $50 \mathrm{ml}$ water to which has been added $42 \mathrm{mg}$ sodium bicarbonate. The mixture was shaken vigorously, diluted to $200 \mathrm{ml}$ with water, filtered, stored in an amber bottle and kept in the refrigerator.

The dye was standardized daily by taking three $2 \mathrm{ml}$ aliquots ascorbic acid standard solution and transferring into each of three $50 \mathrm{ml}$ Erlenmeyer flask containing $5 \mathrm{ml}$ $\mathrm{HPO}_{3}-\mathrm{HOAc}$ solution. The solution was titrated rapidly with the dye from a $50 \mathrm{ml}$ burette until light but distinct rose pink persisted. (Each titration required $16.5 \mathrm{ml}$ dye solution as compared to the expected value $15 \mathrm{ml}$ stated by AOAC). Similarly, 3 blanks composed of $7 \mathrm{ml} \mathrm{HPO}_{3^{-}}$ $\mathrm{HO}$ Ac plus volume water equal to volume dye were titrated with dye. Average blank (usually $0.1 \mathrm{ml}$ ) was subtracted from standardized titrations.

\section{Procedure}

Vitamin C was determined using fifty gram of each sample was homogenized for $3 \mathrm{~min}$ in $150 \mathrm{ml}$ of aqueous $3 \%$ metaphosphoric acid, $8 \%$ acetic acid using a warring blender. The slurry was made up to $200 \mathrm{ml}$ with the extracting solution and vacuum filtered using a Buchner funnel and Whatman No. 1 filter paper to give the extract. The vitamin $\mathrm{C}$ content was determined by directly titrating $50 \mathrm{ml}$ of the extract with dye solution $(2,6$ dichlorophenol indophenols) for 15 seconds. The procedure was followed for the standard as well.

Calculation: $\mathrm{mg}$ ascorbic acid $/ 1 \mathrm{~g}$ sample $=\mathrm{C} \times \mathrm{V} \times$ (DF / Wt)

Where: $\mathrm{C}=\mathrm{mg}$ ascorbic acid $1 \mathrm{ml}$ dye; $\mathrm{V}=$ volume of dye used for titration of diluted sample; $\mathrm{DF}=$ dilution factor; $\mathrm{Wt}$ $=$ weight of sample.

\section{Determination of vitamin E content}

Vitamin E was determined using Pearson (1976) method. One gram of the samples each was weighed into a 100 $\mathrm{ml}$ flask. Then, $10 \mathrm{ml}$ of the clear solution was pipette into a test tube and heated in a water bath at $90{ }^{\circ} \mathrm{C}$ for 30 mins. It was allowed to cool and the absorbance was read in a spectrophotometer at wavelength of $470 \mathrm{~nm}$. The blank and the standard were prepared and the absorbance was taken at $470 \mathrm{~nm}$ wavelength.

Vitamin $E$ in $\mathrm{mg} / 100 \mathrm{~g}=(\mathrm{a}-\mathrm{b}) \mathrm{c} /(\mathrm{s}-\mathrm{bw})$

Where: $a=$ absorbance of test sample; $b=$ absorbance of the standard solution; $c=$ concentration of standard in $\mathrm{mg} / 100 \mathrm{~g} ; \mathrm{w}=$ weight of the sample used

\section{Determination of Thiamin (Vitamin $\mathrm{B}_{1}$ ) Content}

Thiamin was determined using AOAC (2010) procedure. A $75 \mathrm{ml}$ of $0.2 \mathrm{~N} \mathrm{HCl}$ was added to $2 \mathrm{~g}$ of sample and the mixture boiled over a water bath. After cooling, $5 \mathrm{ml}$ of phosphatase (enzyme solution) was then be added and the mixture incubated at $37{ }^{\circ} \mathrm{C}$ overnight. The solution was placed in $100 \mathrm{ml}$ volumetric flask and the volume made up with distilled $\mathrm{H}_{2} \mathrm{O}$. The solution was then be filtered and the filtrate purified by passing through silicate column. To $25 \mathrm{ml}$ of the filtrate in a conical flask was added $5 \mathrm{ml}$ acidic $\mathrm{KCl}$ eluate, $3 \mathrm{ml}$ of alkaline ferricyanide solution, and $15 \mathrm{ml}$ isobutanol, and shaken for $2 \mathrm{~min}$. The solution was then allowed to separate and the alcohol layer taken. Then, $3 \mathrm{~g}$ of anhydrous sodium sulphate was 
added to the alcohol layer. A $5 \mathrm{ml}$ of thiamine solution was accurately measured into another $50 \mathrm{ml}$ stoppered flask. The oxidation and extraction of thiochrome as already carried out with the sample was repeated using the thiamin solution. Then, $3 \mathrm{ml}$ of $15 \% \mathrm{NaOH}$ was added to the blank instead of alkaline ferricyanide. The blank sample solution was poured into fluorescence reading tube and reading taken at the expression:

$\%$ thiamin $=X / Y \times 1 / 5 \times 25 / \mathrm{V} \times 100 / \mathrm{W}$

Where: $W=$ weight of sample; $X=$ reading of sample reading of blank; $Y=$ reading of thiamin standard reading of blank standard; $V=$ volume of solution used for test on the column.

\section{Determination of Mineral Content}

Calcium, iron, zinc, copper and manganese content was determined using atomic absorption spectrophotometer (AAS)

Calcium was determined using AAS as described by AOAC (2010). About $1.0 \mathrm{~g}$ of the sample was first digested with $20 \mathrm{ml}$ of acid mixture $[650 \mathrm{ml}$ concentrated $\mathrm{HNO}_{3} ; 80 \mathrm{ml}$ Perchloric acid (PCA); $20 \mathrm{ml}$ conc. $\left.\mathrm{H}_{2} \mathrm{SO}_{4}\right]$ and aliquots of the diluted clear digest used for atomic absorption spectrophotometer using filters that match the different elements.

\section{Sample preparation}

One gram of each dried sample was weighed out into a digestion flask and $20 \mathrm{ml}$ of the add mixture was added $\left(650 \mathrm{ml}\right.$ concentrated $\mathrm{HNO}_{3} ; 80 \mathrm{ml}$ PCA; $20 \mathrm{ml}$ concentrated $\mathrm{H}_{2} \mathrm{SO}_{4}$ ). The flask was heated until a clear digest is obtained. The digest was diluted with distilled water to the $500 \mathrm{ml}$ mark. Appropriated dilution was then made for each element. For the determination of Calcium, enough $\mathrm{SrCl}_{2}$ solution containing $10,000 \mathrm{mg} / \mathrm{ml}$ was added to yield a $1,500 \mathrm{mg} / \mathrm{ml}$ of $\mathrm{Sr}^{2+}$ in the final solution. Calibration curves were prepared for each element using standard solution (Appendix 1). The appropriate lamps and correct wavelength for each element are usually specified on the instruction manual of the instrument.

\section{Determination of anti-nutritional factors}

\section{Determination of tannin content}

The Folin - Denis spectrophotometric method as described by Pearson (1976) was used. One gram of the sample was dispersed in $10 \mathrm{ml}$ distilled water and agitated. This was left to stand for $30 \mathrm{~min}$ at room temperature and shaken every $5 \mathrm{~min}$. After this, it was centrifuged at $3000 \mathrm{rpm}$ for 5 min to obtain the extract. A quantity of $2.5 \mathrm{ml}$ of standard tannic acid solution was dispersed into a separate $5 \mathrm{ml}$ flask. Then, a quantity of $0.1 \mathrm{ml}$ Folin - Denis reagent was measured into each flask, followed by $2.5 \mathrm{ml}$ of saturated $\mathrm{Na}_{2} \mathrm{CO}_{3}$ solution. The mixture was diluted to the mark in the flask $(50 \mathrm{ml})$ and incubated for $90 \mathrm{~min}$ at room temperature. The absorbance was measured at $250 \mathrm{~nm}$. The reading was taken, with the reagent blank at zero.

Tannin content was given as follows

Tannin $(\mathrm{g} / 100 \mathrm{~g})=$ conc. of standard $\mathrm{x}$ absorbance of sample

\section{Determination of trypsin inhibitor content}

The method of Kakade et al. (1995) was employed in the determination of trypsin inhibitor activity. A $0.5 \mathrm{~g}$ of the sample was dispensed in $50 \mathrm{ml}$ of $0.5 \mathrm{M} \mathrm{NaCl}$ solution and shaken for $30 \mathrm{~min}$ at room temperature. The mixture was centrifuged and the supernatant was used as the extract. An assay for trypsin inhibitor activity involved mixing a portion (1 ml) of the extract with $90 \mathrm{ml}$ of $0.03 \%$ Trypsin substrate (BAPA) in a test tube containing $1 \mathrm{ml}$ of $0.6 \%$ trypsin enzyme solution. After mixing, the mixture was allowed to stand for $15 \mathrm{~min}$ before its absorbance was reached at $410 \mathrm{~nm}$ in a spectrophotometer. A control which consists of $1 \mathrm{ml}$ enzyme solution in $9 \mathrm{mls}$ of trypsin substrate (BAPA) but no extract was set up as described above and its absorbance was also measured. Trypsin inhibitor activity was calculated using the formula below:

TUl / $\mathrm{g}=1 / \mathrm{w} \times$ au / $0.01-$ as $\times \mathrm{vf} / \mathrm{va}$

Where: $\mathrm{W}=$ Weight of sample; au = Absorbance of sample at $410 \mathrm{~nm}$; as = Absorbance of control; vf $=$ Total extract volume; $\mathrm{va}=$ Volume of extract analyzed.

\section{Determination of total phenols}

Total phenol (TP) was determined calorimetrically using Folin ciocalteu reagent, as described by Pasko et al. (2008). Total phenol assay was conducted by mixing 2.7 $\mathrm{ml}$ of de-ionized water, $0.3 \mathrm{ml}$ of extracts, $0.3 \mathrm{ml} \mathrm{Na}_{2} \mathrm{CO}_{3}$ and $0.15 \mathrm{ml}$ Folin ciocalteu reagent. Absorbance of mixture was measured at $725 \mathrm{~nm}$ using the spectrophotometer (Jasco UV-530; Medson, Paczkowo, Poland).

\section{Determination of hydrocyanic acid content}

This was determined by the alkaline picrate colorimetric method of Armtfiled et al. (1985). A measured weight of each sample $(0.5 \mathrm{~g})$ was dispensed in $200 \mathrm{ml}$ of distilled water in a conical flask and mixed properly. A strip of alkaline picrate paper was suspended over the mixture 
Nwaoha and Itoje, 073

Table 1 . Proportions for the blending of prawn meat and starch (from cassava, pink and orange fleshed sweet potatoes)

\begin{tabular}{|c|c|c|}
\hline Raw material & Starch & Prawn \\
\hline \multirow{3}{*}{ Cassava starch } & 100 & 0 \\
\hline & 90 & 10 \\
\hline & 80 & 20 \\
\hline \multirow[t]{3}{*}{ Pink fleshed sweet potato starch } & 100 & 0 \\
\hline & 90 & 10 \\
\hline & 80 & 20 \\
\hline \multirow[t]{3}{*}{ Orange fleshed sweet potato starch } & 100 & 0 \\
\hline & 90 & 10 \\
\hline & 80 & 20 \\
\hline
\end{tabular}

with the aid of rubber stopper in a way that the paper did not touch the surface of the mixture. The set up was incubated for 18 hours at room temperature and at the end of the incubation period. The picrate paper was carefully removed and eluted in $60 \mathrm{ml}$ of distilled water. Meanwhile, a standard cyanide solution $(\mathrm{KCN})$ was prepared and treated as described above. The absorbance of the elutes from the standard and the samples were measured in a spectrophotometer at 540 $\mathrm{nm}$ with the reagent blank at zero. The cyanide content ( $\mathrm{HCN} \mathrm{mg} / \mathrm{kg}$ ) was calculated using the formula:

$\mathrm{HCN} \mathrm{mg} \mathrm{/} \mathrm{kg}=100 / 1 \times \mathrm{Au} / \mathrm{As} \times \mathrm{C} \times \mathrm{D}$

Where; $\mathrm{W}=$ Weight of the samples analyzed; $\mathrm{Au}=$ Absorbance of the sample; As = Absorbance of the standard HCN solution; $\mathrm{C}=$ Concentration $(\mathrm{mg} / \mathrm{ml}$ of standard HCN solution); $\mathrm{D}=$ Dilution factor (where applicable).

\section{Microbial Analysis}

\section{Determination of Mould Count}

The pour plate method was used as described by Harrigan and McCance (1976). About $0.1 \mathrm{ml}$ of the sample dilution was transferred from each dilution corresponding plates and $15 \mathrm{ml}$ of sterile Sabourand Dextrose Agar (SDA) medium was poured and mixed thoroughly with the inocula by rocking the plates. The plates was incubated at ambient temperature for three days after which colonies formed was counted and expressed as colony forming units per gram (cfu/g). The samples were stored for one month and the samples were drawn and analyzed at one week interval.

\section{Sensory evaluation}

The colour, texture, mouth-feel, taste, aftertaste and overall acceptability of the prawn cracker were assessed. Twenty semi-trained panelists were maintained for assessment. The panel was drawn from staff and students of the Department of Food Science and Technology, University of Nigeria, Nsukka and trained on how to use the test method. A nine point Hedonic scale was used, where 1 represented extremely dislike and 9 represented extremely like (Ihekoronye and Ngoddy, 1985).

\section{Data analysis and Experimental Design}

Data was analyzed using the method of Steele and Torrie (1980). Data was obtained in duplicate and the errors reported as standard deviations from means. The Completely Randomized Design (CRD) was used. Mean separation was done by one-way ANOVA using Statistical Package for Social Sciences (SPSS) version 20. Significance was accepted at $p<0.05$ level.

\section{RESULTS AND DISCUSSION}

\section{Functional properties of tapioca, pink and orange fleshed sweet potato starches}

The starches (Plate 1) had swelling power which indicated that the starch obtained were highly restricted. The pink fleshed sweet potato starch $(5.35 \%)$ had significantly $(p<0.05)$ lower swelling power than that of cassava $(5.75 \%)$ and orange fleshed sweet potato starch $(5.60 \%)$ probably due to the higher amylose contents of the latter two starches (Table 2). Leach et al. (1959) reported that the amylose acts both as diluent and inhibitor of swelling. The lower swelling power of the pink fleshed sweet potato starch suggests a more highly ordered arrangement in its granules than the other two starches. The ability to absorb water is a very important property of all flours and starches used in food preparations.

The range of water absorption capacity $(1.85-2.19$ $\%)$ observed for the different starches showed that cassava starch had the highest $(2.19 \%)$ while pink fleshed sweet potato starch had the lowest $(1.85 \%)$ water absorption capacity. The starch samples were significantly $(p<0.05)$ different in their water absorption capacity. The observed water absorption capacity of the 
Table 2. Functional properties of starch extracted from cassava, and sweet potato starches

\begin{tabular}{lcccr}
\hline Sample & WAC (\%) & SC (\%) & OAC (\%) & Bulk density (g/ml) \\
\hline OPS & $1.85^{\mathrm{C}} \pm 0.01$ & $5.60^{\mathrm{b}} \pm 0.01$ & $1.85^{\mathrm{C}} \pm 0.02$ & $68.96^{\mathrm{C}} \pm 0.00$ \\
PPS & $2.10^{\mathrm{b}} \pm 0.03$ & $5.35^{\mathrm{c}} \pm 0.02$ & $1.94^{\mathrm{b}} \pm 0.01$ & $69.26^{\mathrm{b}} \pm 0.02$ \\
CAS & $2.19^{\mathrm{a}} \pm 0.02$ & $5.75^{\mathrm{a}} \pm 0.01$ & $2.04^{\mathrm{a}} \pm 0.01$ & $72.44^{\mathrm{a}} \pm 0.02$ \\
\hline
\end{tabular}

Values are means \pm standard deviation of duplicate determinations. Values with the same superscript within a column were not significantly different $(p<0.05)$

Key: OPS $\rightarrow$ Orange fleshed sweet potato starch; PPS $\rightarrow$ Pink fleshed sweet potato starch; CAS $\rightarrow$ cassava starch /Cassava starch; WAC $\rightarrow$ Water absorption capacity; SC $\rightarrow$ Swelling capacity; OAC $\rightarrow$ Oil absorption capacity

Table 3. Particle size distribution starch extracted from cassava and sweet potato starches

\begin{tabular}{llllc}
\hline & \multicolumn{4}{c}{ Pore size } \\
Sample & $\mathbf{1 ~} \mathbf{~ m m}(\boldsymbol{\mu m})$ & $\mathbf{7 1 0} \mathbf{~ m m}(\boldsymbol{\mu m})$ & $\mathbf{5 0 0} \mathbf{~ m m}(\boldsymbol{\mu m})$ & base $\mathbf{~ m m}(\boldsymbol{\mu m})$ \\
\hline OPC & $18.26^{\mathrm{a}} \pm 0.01$ & $24.78^{\mathrm{b}} \pm 0.00$ & $28.43^{\mathrm{a}} \pm 0.02$ & $28.52^{\mathrm{a}} \pm 0.00$ \\
PPS & $17.62^{\mathrm{c}} \pm 0.00$ & $25.06^{\mathrm{a}} \pm 0.01$ & $28.55^{\mathrm{a}} \pm 0.00$ & $28.76^{\mathrm{a}} \pm 0.01$ \\
CAS & $18.07^{\mathrm{b}} \pm 0.02$ & $23.65^{\mathrm{c}} \pm 0.01$ & $28.43^{\mathrm{a}} \pm 2.12$ & $29.84^{\mathrm{a}} \pm 2.14$ \\
\hline
\end{tabular}

Values are means \pm standard deviation of duplicate determinations. Values with the same superscript within a column were not significantly different $(p>0.05)$

Key: $1 \mathrm{~mm}(\mu \mathrm{m})+710 \mathrm{~mm}(\mu \mathrm{m})+500 \mathrm{~mm}(\mu \mathrm{m})+$ base $\mathrm{mm}(\mu \mathrm{m})=100 \%$

OPC $=$ Orange fleshed sweet potato starch; $P P S=$ Pink fleshed sweet potato starch; $C A S=$ Cassava starch

three native starch as used in this study ware lower than those reported by Omodamiro et al. (2007) for lafun and starch from improved cassava. The ability of food materials to absorb water could sometimes attribute to its proteins content (Kinsella, 1976). The observed water absorption capacity of the starches studied cannot, however, be attributed to their protein content since cassava and cassava starch in particular is very poor in protein. The observed differences in water absorbed may have been due to the nature of the starch (Sathe and Salunkhe, 1981).

The oil absorption capacity value of the starch samples used in this study ranged between $1.85 \%$ and $2.04 \%$. Cassava starch had the highest value $(2.04 \%)$ and orange fleshed sweet potato had the lowest $(1.85 \%)$ value. The oil absorption value of the starch samples were significantly $(p<0.05)$ different.

Bulk density is a function of the closeness of the packaging material. Orange fleshed sweet potato starch, pink fleshed sweet potato and cassava starch recorded values of $68.96,69.26$ and $72.44 \mathrm{~g} / \mathrm{ml}$, respectively (Table 2). There were significant $(p<0.05)$ differences recorded between cassava starch and pink fleshed sweet potato flour bulk densities, while non significant effect was recorded for orange fleshed sweet potato starch and pink fleshed sweet potato starch. Peleg and Hollenbach (1983) emphasized that density variation of particulates is based only on moisture content and particle size. The bulk density of the flours could be used to determine their handling requirement because it is the function of mass and volume.

Table 3 shows the particle size distribution starch extracted from cassava, pink and orange fleshed sweet potato. The particle size distribution of the starch samples extracted from the cassava ranged from $18.07-29.84$ $(\mu \mathrm{m})$, pink ranged from $17.62-28.76(\mu \mathrm{m})$ and orange fleshed sweet potato had $18.26-28.52(\mu \mathrm{m})$ (Table 3). For pore size $1 \mathrm{~mm}(\mu \mathrm{m})$, pink fleshed sweet potato starch had the least particle size distribution of $17.62 \mu \mathrm{m}$ followed by cassava starch and then orange fleshed sweet potato starch $18.26(\mu \mathrm{m})$. For $710 \mathrm{~mm}(\mu \mathrm{m})$, cassava starch had the least particle size distribution of $23.65(\mu \mathrm{m})$ followed by orange fleshed sweet potato starch and then pink fleshed sweet potato starch 25.06 $(\mu \mathrm{m})$. For $500 \mathrm{~mm}(\mu \mathrm{m})$, orange fleshed sweet potato starch had the least particle size distribution of 28.43 $(\mu \mathrm{m})$ followed by cassava starch 28.43 and then pink fleshed sweet potato starch $28.55(\mu \mathrm{m})$. For the base $(\mu \mathrm{m})$, orange fleshed sweet potato starch had the least size distribution of $28.52(\mu \mathrm{m})$ followed by pink fleshed sweet potato starch $28.76(\mu \mathrm{m})$ and then, cassava starch had $29.84(\mu \mathrm{m})$. The particle size of starch is one of the most important characteristics, which might influence other physicochemical properties such as swelling power; paste clarity, and water-binding capacity (Singh et al., 2003). Based on these properties these starches may find several different applications in the food industry, particularly for products that require starch of a smaller particle size which allows for smooth textured starch gel (Tattiyakul et al., 2006). Previous studies have indicated this, such that, fine granules of taro starch improved binding and reduced breakage of a snack product (Huang et al., 2006). Although, the starches had different particle size distribution, it is probably due to the similarity in their chemical composition and identical values obtained for their bulk density (Sefa-Dedeh, 1989). Cassava flour, 
Table 4. Pasting properties of the starch from cassava and sweet potato starches

\begin{tabular}{llllllll}
\hline & $\begin{array}{l}\text { Peak } \\
\text { viscosity }\end{array}$ & $\begin{array}{l}\text { Viscosity } \\
\text { trough put }\end{array}$ & Breakdown & $\begin{array}{l}\text { Final } \\
\text { viscosity }\end{array}$ & Setback & $\begin{array}{l}\text { Pasting } \\
\text { time } \\
\text { (mins) }\end{array}$ & $\begin{array}{l}\text { Pasting } \\
\text { temp } \\
\mathbf{C})\end{array}$ \\
\hline OPS & 141.75 & 112.33 & 29.42 & 165.67 & 53.33 & 5.60 & 83.66 \\
$\mathbf{(}{ }^{\circ}$ \\
PPS & 274.17 & 94.33 & 179.84 & 131.58 & 37.25 & 5.35 & 82.55 \\
CAS & 168.92 & 128.75 & 40.17 & 207.17 & 78.42 & 5.75 & 84.18
\end{tabular}

Values are means \pm standard deviation of duplicate determinations. Values with the same superscript within a column were not significantly different $(p>0.05)$ Key: OPS $\rightarrow$ Orange fleshed sweet potato starch; PPS $\rightarrow$ Pink fleshed sweet potato starch; CAS $\rightarrow$ cassava starch; P / Viscosity $\rightarrow$ peak viscosity; V / trough $\rightarrow$ Viscosity trough; B / down $\rightarrow$ breakdown; F / Viscosity $\rightarrow$ Final viscosity, $\mathrm{RVU} \rightarrow$ Rapid Visco Units

which had a medium particle size distribution (Figure 1), had the lowest bulk density. This could be attributed to the relatively lower protein and fat contents of cassava.

Table 4 showed the pasting properties of starch samples from orange flesh sweet potato starch, cassava starch and pink fleshed sweet potato starch. Peak viscosities, which is the maximum viscosity developed during or soon after the heating portion, were 141.75, 168.92 and 274.17 RVU (Rapid Visco Units). Pink fleshed sweet potato starch gave the highest $(274.17$ RVU at a temperature of $82.18{ }^{\circ} \mathrm{C}$ in $5.35 \mathrm{~min}$ ) while sample orange fleshed sweet potato starch had the lowest $\left(141.75 \mathrm{RVU}\right.$ at a temperature of $83.66^{\circ} \mathrm{C}$ in 5.60 $\min )$. There were significant differences $(p<0.005)$ in the peak viscosities of the starch samples. This variation in the peak viscosity might be as a result of the amylose contents of the starches. Oguntunde (1987) reported that the associative bonding of the amylose fraction is responsible for the structure and pasting behaviour of the starch granule. The viscosity (or more correctly the consistency of a cooked starch paste) simply reflects the resistance to stirring of the swollen mass gel particles. Peak viscosity has been reported to be closely associated with the degree of starch damage and high starch damage results in high peak viscosity (Sanni et al., 2001).

The results show that there were significant differences $(p<0.05)$ in the pasting temperatures of the three starches. Pasting temperatures of the starches were $83.66^{\circ} \mathrm{C}$ for orange fleshed sweet potato starch, $82.55^{\circ} \mathrm{C}$ for pink fleshed sweet potato starch and 84.18 ${ }^{\circ} \mathrm{C}$ for cassava starch respectively. The gelatinization temperature obtained was not similar to the results for CMD resistant cassava starch 64.5 to $74.0{ }^{\circ} \mathrm{C}$ (Omodamiro et al., 2007). The pasting temperature is one of the pasting properties of which provide an indication of the minimum temperature required for sample cooking, energy cost involved and other components stability. Starch from sample pink fleshed sweet potato starch would cook faster and less energy consumed, thereby saving cost and time compared to the other starch samples because of its lower pasting temperature.

The breakdown viscosity varied from 29.42 to 179.84 RVU. Pink fleshed sweet potato starch had the highest
(179.84 RVU) and Orange fleshed sweet potato starch had (29.42 RVU). The values of breakdown viscosity of the starch samples were significantly different $(p<0.05)$. Adebowale et al. (2005) reported that the higher the breakdown in viscosity, the lower the ability of the sample to withstand heating and shear stress during cooking. Hence, the starch sample from orange fleshed sweet potato starch and cassava starch would withstand heating and shear stress compared to starch samples from pink fleshed sweet potato starch because of their low breakdown value.

The final viscosity ranged from 165.67 to 207.17 RVU. The starch sample from Tapioca starch had the highest final viscosity (207.17 RVU), while sample from Pink fleshed sweet potato starch had the lowest final viscosity (165.67 RVU). There was significant difference $(p>0.05)$ in the final viscosity of the starch samples. Shimelis et al. (2006) reported that final viscosity is used to indicate the ability of starch to form paste or gel after cooling less stability of starch paste could be commonly accompanied with high value of breakdown. This implied that starch paste from cassava starch would be less stable after cooling compared to the other starch samples. The variation in the final viscosity might be due to the simple kinetic effect of cooling on viscosity and the reassociation of starch molecules in the samples. The set back viscosity of the starch samples varied from 53.33 to 78.42 RVU. Cassava starch had the highest (78.42 RVU) and pink fleshed sweet potato starch was the lowest $(9.75 \mathrm{RVU})$. There was significant difference $(p<$ 0.05 ) in the set back viscosity of the starch samples. Sanni et al. (2001) reported that lower set back viscosity during the cooling of garri indicates higher resistance to retrogradation. This means that cassava starch would exhibit a higher resistance to retrogradation.

\section{Proximate composition (\%) of prawn crackers produced from blends of cassava, pink and orange fleshed sweet potato starches}

Table 5 shows the proximate composition (\%) and $\mathrm{pH}$ of prawn crackers produced from blends of cassava, pink and orange fleshed sweet potato starch. 
076 Afr. J. Food Sci. Technol.

Table 5. Proximate composition (\%) and pH of prawn crackers formulated from blends of cassava, pink and orange fleshed sweet potato starch

\begin{tabular}{|c|c|c|c|c|c|c|c|}
\hline Samples & $\begin{array}{l}\text { Moisture } \\
\text { (\%) }\end{array}$ & $\begin{array}{l}\text { Protein } \\
\text { (\%) }\end{array}$ & $\begin{array}{l}\text { Fat } \\
(\%)\end{array}$ & $\begin{array}{l}\text { Carbohydrate } \\
\text { (\%) }\end{array}$ & $\begin{array}{l}\text { Ash } \\
(\%)\end{array}$ & $\begin{array}{l}\text { Crude fibre } \\
\text { (\%) }\end{array}$ & $\mathrm{pH}$ \\
\hline CPC (100:0) & $3.91^{\mathrm{d}} \pm 0.05$ & $2.68^{n} \pm 0.03$ & $3.71^{g} \pm 0.00$ & $87.34^{a} \pm 0.00$ & $1.79^{n} \pm 0.04$ & $0.56^{9} \pm 0.06$ & $5.30^{9} \pm 0.00$ \\
\hline CPC $(90: 10)$ & $3.48 \mathrm{e} \pm 0.06$ & $7.46^{\mathrm{e}} \pm 0.03$ & $8.40^{\mathrm{d}} \pm 0.01$ & $77.74^{\mathrm{e}} \pm 0.00$ & $1.97^{g} \pm 0.00$ & $0.59^{9} \pm 0.03$ & $7.10^{\mathrm{bc}} \pm 0.10$ \\
\hline CPC (80:20) & $4.09^{\mathrm{e}} \pm 0.05$ & $16.92^{c} \pm 0.04$ & $13.62^{a} \pm 0.01$ & $60.40^{g} \pm 0.00$ & $3.31^{d^{d}} \pm 0.02$ & $1.66^{\mathrm{d}} \pm 0.04$ & $5.46^{g} \pm 0.11$ \\
\hline PPC (100:0) & $3.45^{\mathrm{e}} \pm 0.06$ & $3.91^{9} \pm 0.02$ & $2.14^{\mathrm{h}} \pm 0.00$ & $84.96^{c} \pm 0.00$ & $3.96^{\mathrm{b}} \pm 0.04$ & $1.57^{\mathrm{de}} \pm 0.12$ & $8.23^{a} \pm 0.05$ \\
\hline PPC (90:10) & $2.41^{\mathrm{g}} \pm 0.02$ & $7.74^{\mathrm{d}} \pm 0.03$ & $7.47^{\mathrm{e}} \pm 0.00$ & $80.85^{d} \pm 0.01$ & $0.07^{1} \pm 0.02$ & $1.48^{\mathrm{e}} \pm 0.08$ & $6.66^{\mathrm{de}} \pm 0.05$ \\
\hline PPC (80:20) & $5.63^{\mathrm{a}} \pm 0.02$ & $18.80^{\mathrm{b}} \pm 0.01$ & $12.03^{c} \pm 0.00$ & $56.48^{\mathrm{h}} \pm 0.01$ & $4.24^{\mathrm{a}} \pm 0.06$ & $2.82^{\mathrm{b}} \pm 0.02$ & $7.26^{\mathrm{b}} \pm 0.05$ \\
\hline OPC $(100: 0)$ & $3.16^{\dagger} \pm 0.02$ & $4.09^{\dagger} \pm 0.04$ & $1.67^{\mathrm{c}} \pm 0.00$ & $87.07^{\mathrm{d}} \pm 0.02$ & $3.03^{\mathrm{e}} \pm 0.49$ & $0.95^{\dagger} \pm 0.02$ & $6.23^{\dagger} \pm 0.57$ \\
\hline OPC $(90: 10)$ & $3.47^{\mathrm{e}} \pm 0.04$ & $7.71^{\mathrm{d}} \pm 0.01$ & $6.67^{\dagger} \pm 0.00$ & $76.78^{\dagger} \pm 0.01$ & $2.88^{\dagger} \pm 0.14$ & $2.49^{c} \pm 0.02$ & $6.76^{\mathrm{cd}} \pm 0.23$ \\
\hline OPC $(80: 20)$ & $5.17^{\mathrm{b}} \pm 0.04$ & $19.64^{a} \pm 0.02$ & $12.15^{b} \pm 0.00$ & $52.92^{1} \pm 0.01$ & $3.70^{c} \pm 0.02$ & $3.43^{\mathrm{a}} \pm 0.08$ & $7.03^{\mathrm{bc}} \pm 0.05$ \\
\hline
\end{tabular}

Values are means \pm standard deviation of duplicate determinations. Values with the same superscript within a column were not significantly different $(p$ $>0.05$ ).

Key: CPC (100:0) $\rightarrow$ cassava based prawn cracker (control); CPC (90:10) $\rightarrow$ cassava based prawn cracker; CPC (80:20) $\rightarrow$ cassava based prawn cracker; PPC (100:0) $=$ Pink fleshed based prawn cracker (control); PPC (90:10) $\rightarrow$ Pink fleshed based prawn cracker; PPC (80:20) $\rightarrow$ Pink fleshed based prawn cracker; OPC (100:0) $\rightarrow$ Orange fleshed based prawn cracker (control); OPC (90:10) $\rightarrow$ Orange fleshed based prawn cracker; OPC $(80: 20) \rightarrow$ Orange fleshed based prawn cracker

There were significant differences $(p<0.05)$ in the proximate composition of the samples except for moisture content as shown in Table 5. As a dried product, the low moisture content of the prawn crackers was expected. The moisture content of the product ranged from 2.41 to $5.63 \%$. Pink fleshed based prawn cracker sample $(80: 20)$ had the highest score and pink fleshed based prawn cracker sample (90:10) had the lowest. Commercial fish crackers (unfried crackers) studied had moisture content between 9.37 and $13.83 \%$. Yu (1991b), King (2002) and Huda et al. (2007) also reported moisture content of 9, 12 and approximately $9-13 \%$, respectively. These suggest that the product's low moisture content might be attributed to frying. Control of moisture content in crackers might be necessary to optimize the quality of the product and the production process. Mohamed et al. (1988) concluded that insufficient water might lead to incomplete gelatinization of starch during the steaming process. Thus, fish crackers do not expand well. Furthermore, excess water could cause a decrease in expansion and result in a thinner fish cracker after drying. In addition, too much moisture also results in dough thereby making it difficult to slice.

The protein content of the prawn crackers ranged from 2.68 to $19.64 \%$. Orange fleshed based prawn cracker $(80: 20)$ had the highest score and sample cassava based prawn cracker (100:0) had the lowest. It is commonly known that fish is a good source of protein while cassava, pink and orange fleshed sweet potato starch contains a lower amount of protein. According to Yu (1991a); Peranginangin et al. (1996); Huda et al. (2000); King (2002), the more fish used in the crackers, the higher the protein content of the crackers. Thus, the low contents of protein indicate low fish content in the formulation. Increasing the fish proportion not only increases protein content but also increases the fat content. A similar trend, but with different degrees of increase, was also reported by Yu (1991b), Peranginangin et al. 
Table 6. Vitamin content of prawn crackers produced with blend from cassava, pink and orange fleshed sweet potato starch

\begin{tabular}{|c|c|c|c|c|c|c|c|c|}
\hline Samples & $\begin{array}{l}\text { Carotenoid } \\
(\mathrm{mg} / 100 \mathrm{~kg})\end{array}$ & $\begin{array}{l}\text { Vitamin } B_{1} \\
(\mathrm{mg} / 100 \mathrm{~kg})\end{array}$ & $\begin{array}{l}\text { Vitamin } B_{3} \\
(\mathrm{mg} / 100 \mathrm{~kg})\end{array}$ & $\begin{array}{l}\text { Vitamin } B_{6} \\
\text { (mg/100kg) }\end{array}$ & $\begin{array}{l}\text { Vitamin } B_{12} \\
(\mathrm{mg} / 100 \mathrm{~kg})\end{array}$ & $\begin{array}{l}\text { Vitamin C } \\
\text { (mg/100kg) }\end{array}$ & $\begin{array}{l}\text { Vitamin D } \\
\text { (mg/100kg) }\end{array}$ & $\begin{array}{l}\text { Vitamin E } \\
\text { (mg/100kg) }\end{array}$ \\
\hline $\begin{array}{l}\operatorname{CPC}(100: 0) \\
\operatorname{CPC}(90: 10) \\
\operatorname{CPC}(80: 20) \\
\operatorname{PPC}(100: 0) \\
\operatorname{PPC}(90: 10) \\
\operatorname{PPC}(80: 20) \\
\operatorname{OPC}(100: 0) \\
\operatorname{OPC}(90: 10) \\
\operatorname{OPC}(80: 20)\end{array}$ & $\begin{array}{l}113.23^{\dagger} \pm 0.00 \\
116.25^{\mathrm{e}} \pm 0.00 \\
118.85^{\mathrm{d}} \pm 0.00 \\
120.43^{\mathrm{c}} \pm 0.00 \\
123.25^{\mathrm{b}} \pm 0.00 \\
122.14^{\mathrm{b}} \pm 0.01 \\
123.25^{\mathrm{b}} \pm 0.00 \\
126.16^{\mathrm{a}} \pm 0.00 \\
128.25^{\mathrm{a}} \pm 0.01\end{array}$ & $\begin{array}{l}0.05^{\mathrm{b}} \pm 0.00 \\
0.05^{\mathrm{b}} \pm 0.00 \\
0.06^{\mathrm{b}} \pm 0.00 \\
0.05^{\mathrm{b}} \pm 0.00 \\
0.65^{\mathrm{a}} \pm 0.05 \\
0.05^{\mathrm{b}} \pm 0.05 \\
0.05^{\mathrm{b}} \pm 0.00 \\
0.70^{\mathrm{b}} \pm 0.01 \\
0.05^{\mathrm{b}} \pm 0.00\end{array}$ & $\begin{array}{l}0.65^{\mathrm{d}} \pm 0.00 \\
0.77^{\mathrm{b}} \pm 0.00 \\
0.87^{\mathrm{a}} \pm 0.00 \\
0.07^{\dagger} \pm 0.01 \\
0.61^{\mathrm{e}} \pm 0.00 \\
0.71^{\mathrm{c}} \pm 0.01 \\
0.04^{\mathrm{g}} \pm 0.00 \\
0.67^{\mathrm{d}} \pm 0.00 \\
0.75^{\mathrm{b}} \pm 0.00\end{array}$ & $\begin{array}{l}0.070^{\mathrm{e}} \pm 0.0 \\
0.19^{\mathrm{b}} \pm 0.00 \\
0.71^{\mathrm{a}} \pm 0.01 \\
0.09^{\mathrm{d}} \pm 0.00 \\
0.18^{\mathrm{b}} \pm 0.00 \\
0.16^{\mathrm{c}} \pm 0.00 \\
0.10^{\mathrm{d}} \pm 0.00 \\
0.19^{\mathrm{b}} \pm 0.00 \\
0.18^{\mathrm{b}} \pm 0.00\end{array}$ & $\begin{array}{l}0.0025^{\mathrm{c}} \pm 0.00 \\
0.0019^{d} \pm 0.00 \\
0.0027^{\mathrm{c}} \pm 0.00 \\
0.0032^{\mathrm{b}} \pm 0.00 \\
0.0028^{\mathrm{c}} \pm 0.00 \\
0.0033^{\mathrm{b}} \pm 0.00 \\
0.0038^{\mathrm{a}} \pm 0.00 \\
0.0033^{\mathrm{b}} \pm 0.00 \\
0.0037^{\mathrm{a}} \pm 0.00\end{array}$ & $\begin{array}{l}1.02^{\mathrm{a}} \pm 0.16 \\
0.03^{\mathrm{b}} \pm 0.17 \\
0.06^{\mathrm{b}} \pm 0.01 \\
0.00 \\
0.00 \\
0.00 \\
0.00 \\
0.00 \\
0.00\end{array}$ & $\begin{array}{l}0.01^{\mathrm{t}} \pm 0.00 \\
0.16^{\mathrm{b}} \pm 0.00 \\
0.08^{\mathrm{c}} \pm 0.00 \\
0.05^{\mathrm{a}} \pm 0.00 \\
0.19^{\mathrm{a}} \pm 0.00 \\
0.06^{\mathrm{a}} \pm 0.00 \\
0.05^{\mathrm{e}} \pm 0.05 \\
0.18^{\mathrm{a}} \pm 0.00 \\
0.05^{\mathrm{e}} \pm 0.00\end{array}$ & $\begin{array}{l}0.15^{\dagger} \pm 0.00 \\
0.38^{\mathrm{a}} \pm 0.00 \\
0.16^{\dagger} \pm 0.00 \\
0.20^{\mathrm{a}} \pm 0.00 \\
0.25^{\mathrm{c}} \pm 0.00 \\
0.30^{\mathrm{b}} \pm 0.00 \\
0.15^{\dagger} \pm 0.00 \\
0.23^{\mathrm{d}} \pm 0.00 \\
0.38^{\mathrm{a}} \pm 0.00\end{array}$ \\
\hline
\end{tabular}

Values are means \pm standard deviation of duplicate determinations. Values with the same superscript within a column were not significantly different $(p>0.05)$

Key: CPC $(100: 0) \rightarrow$ Cassava based prawn cracker (control); CPC $(90: 10) \rightarrow$ Cassava based prawn cracker; CPC $(80: 20) \rightarrow$ Cassava based prawn cracker; PPC $(100: 0)$ - Pink fleshed based prawn cracker (control); PPC (90:10) $\rightarrow$ Pink fleshed based prawn cracker; PPC (90:10) $\rightarrow$ Pink fleshed based prawn cracker; OPC $(100: 0) \rightarrow$ Orange fleshed based prawn cracker (control); OPC (90:10) $\rightarrow$ Orange fleshed based prawn cracker; OPC (80:20) $\rightarrow$ Orange fleshed based prawn cracker.

1996; 1997) and King (2002)

Starch is not a source of fat. The fat content of prawn crackers ranged from 3.71 to $13.62 \%$. Cassava based prawn cracker $(80: 20)$ had the highest score and cassava based prawn cracker $(100: 0)$ had the lowest. However, the degree of the fat content increased with higher prawn content and from the oil used during frying.

The carbohydrate content of the prawn crackers ranged from 56.48 to $87.34 \%$. From the results obtained, some samples were found to have a high carbohydrate content of more than 70 $\%$; samples cassava based prawn cracker $(100: 0)$, cassava based prawn cracker $(90: 10)$ and orange fleshed based prawn cracker (100:0). Tee et al. (1997) reported carbohydrate value of $66 \%$ and Huda et al. (2001) had $68.3 \%$. The carbohydrate content is reduced by increasing the prawn proportion. However, the carbohydrate content maintained its position as the main component of fish crackers. Huda et al. (2007) reported that commercial fish crackers contained carbohydrates within the range of $65-80 \%$. The higher or lower content of carbohydrates is one of the reasons for the substitution of starch with prawn to provide a more nutritional product.

The ash content observed from the prawn crackers ranged from 0.07 to $4.24 \%$ which was similar to the $4.2 \%$ reported by Tee et al. (1997). pink fleshed based prawn cracker samples $(80: 20)$, pink fleshed based prawn cracker $(100: 0)$, orange fleshed based prawn cracker (80:20), cassava based prawn cracker (90:10), cassava based prawn cracker (80:20), orange fleshed based prawn cracker (90:10), orange fleshed based prawn cracker (100:0) and orange fleshed based prawn cracker (80:20) exhibited significantly $(p<0.05)$ higher ash content compared to the other samples $(p<0.05)$. The variation in the ash content is most probably due to the difference in the amount of prawn used for blending. The higher the amount of prawn used, the higher the ash content was. King (2002) found that ash content increased linearly with an increase in fish content.
The crude fibre content of the prawn crackers ranged from 0.56 to $3.43 \%$. Orange fleshed based prawn cracker sample $(80: 20)$ had the highest score and tapioca based prawn cracker sample (100:0) had the lowest. However, the degree of the crude fibre content increased with higher prawn content.

The $\mathrm{pH}$ content of the prawn crackers ranged from 5.30 to 8.23 pink fleshed based prawn crackers (100:0) had the highest score and cassava based prawn cracker (100:0) had the lowest. The product fell within the range of low acid foods as specified by McCurdy et al. (2009) and within the specified limit of $7.0-8.5$ (Neeraj and Shamas, 2007).

\section{Vitamin composition of prawn crackers produced from cassava starch, pink and orange fleshed sweet potato starch}

Table 6 shows the vitamin content of prawn crackers produced with blend from cassava, pink and orange 
Table 7.Mineral content of prawn cracker blends from cassava, pink and orange fleshed sweet potato starch

\begin{tabular}{|c|c|c|c|c|c|c|c|}
\hline Samples & Sodium & Calcium & Magnesium & Iron & Copper & Zinc & Selenium \\
\hline CPC(80:20) & $81.15^{\mathrm{g}} \pm 0.00$ & $19.10^{\mathrm{C}} \pm 0.00$ & $21.61^{d} \pm 0.00$ & $0.71^{\mathrm{a}} \pm 0.02$ & $0.11^{\mathrm{C}} \pm 0.00$ & $0.15^{\mathrm{e}} \pm 0.00$ & $4.21^{\mathrm{b}} \pm 0.01$ \\
\hline $\operatorname{PPC}(90: 10)$ & $109.01^{\dagger} \pm 0.51$ & $16.58^{\dagger} \pm 0.01$ & $20.23^{i} \pm 0.00$ & $0.22^{\dagger} \pm 0.00$ & $0.36^{\mathrm{b}} \pm 0.00$ & $0.35^{\mathrm{C}} \pm 0.00$ & $2.13^{\mathrm{e}} \pm 0.01$ \\
\hline $\operatorname{PPC}(80: 20)$ & $116.50^{\mathrm{b}} \pm 0.00$ & $19.01^{d} \pm 0.00$ & $21.51^{\mathrm{e}} \pm 0.01$ & $0.38^{d} \pm 0.00$ & $0.48^{a} \pm 0.00$ & $0.43^{\mathrm{a}} \pm 0.01$ & $4.75^{a} \pm 0.00$ \\
\hline OPC(100:0) & $113.46^{\mathrm{c}} \pm 0.43$ & $29.92^{\mathrm{a}} \pm 0.01$ & $23.58^{\mathrm{a}} \pm 0.01$ & $0.58^{\mathrm{b}} \pm 0.01$ & $0.12^{\mathrm{C}} \pm 0.00$ & $0.30^{\mathrm{d}} \pm 0.00$ & $0.66^{\dagger} \pm 0.00$ \\
\hline OPC(90:10) & $110.71^{\mathrm{e}} \pm 0.01$ & $17.34^{\mathrm{e}} \pm 0.00$ & $21.24^{\dagger} \pm 0.01$ & $0.38^{d} \pm 0.03$ & $0.37^{\mathrm{b}} \pm 0.00$ & $0.38^{\mathrm{b}} \pm 0.01$ & $2.34^{d} \pm 0.00$ \\
\hline
\end{tabular}

Values are means \pm standard deviation of duplicate determinations. Values with the same superscript within a column were not significantly different $(p>0.05)$

Key: CPC (100:0) $\rightarrow$ cassava based prawn cracker (control); CPC (90:10) $\rightarrow$ cassava based prawn cracker; CPC (80:20) $\rightarrow$ Cassava based prawn cracker; PPC (100:0) - Pink fleshed based prawn cracker (control); PPC (90:10) $\rightarrow$ Pink fleshed based prawn cracker; PPC (80:20) $\rightarrow$ Pink fleshed based prawn cracker; OPC (100:0) $\rightarrow$ Orange fleshed based prawn cracker (control); OPC (90:10) $\rightarrow$ Orange fleshed based prawn cracker; OPC $(80: 20) \rightarrow$ Orange fleshed based prawn cracker.

Table 8. Anti- nutritional factors of prawn cracker from blends of cassava, pink and orange fleshed sweet potato starch

\begin{tabular}{lllll}
\hline Samples & Tannins & Trypsin inhibitors & Polyphenols & Hydrogen Cyanide \\
\hline CPC (100:0) & - & - & $0.62^{\mathrm{c}} \pm 0.01$ & $1.47^{\mathrm{a}} \pm 0.01$ \\
CPC (90:10) & - & - & $1.02^{\mathrm{a}} \pm 0.00$ & $0.56^{\mathrm{c}} \pm 0.01$ \\
CPC (80:20) & - & - & $0.68^{\mathrm{b}} \pm 0.00$ & $1.05^{\mathrm{b}} \pm 0.02$ \\
PPC (100:0) & $0.18^{\mathrm{a}} \pm 0.00$ & $0.19^{\mathrm{c}} \pm 0.00$ & $0.46^{\mathrm{d}} \pm 0.00$ & $1.02^{\mathrm{a}} \pm 0.00$ \\
PPC (90:10) & $0.13^{\mathrm{b}} \pm 0.00$ & $0.14^{\mathrm{d}} \pm 0.01$ & $0.40^{\mathrm{e}} \pm 0.00$ & $1.00^{\mathrm{a}} \pm 0.02$ \\
PPC (80:20) & $0.16^{\mathrm{a}} \pm 0.00$ & $0.11^{\mathrm{a}} \pm 0.01$ & $0.43^{\mathrm{e}} \pm 0.00$ & $1.01^{\mathrm{a}} \pm 0.00$ \\
OPC (100:0) & $0.16^{\mathrm{a}} \pm 0.00$ & $0.27^{\mathrm{a}} \pm 0.00$ & $0.48^{\mathrm{d}} \pm 0.02$ & $1.00^{\mathrm{a}} \pm 0.00$ \\
OPC (90:10) & $0.11^{\mathrm{c}} \pm 0.02$ & $0.23^{\mathrm{b}} \pm 0.00$ & $0.42^{\mathrm{a}} \pm 0.01$ & $0.98^{\mathrm{a}} \pm 0.00$ \\
OPC (80:20) & $0.13^{\mathrm{b}} \pm 0.01$ & $0.25^{\mathrm{a}} \pm 0.00$ & $0.45^{\mathrm{d}} \pm 0.01$ & $0.89^{\mathrm{b}} \pm 0.00$ \\
\hline
\end{tabular}

Values are means \pm standard deviation of duplicate determinations. Values with the same superscript within a column were not significantly different $(p>$ $0.05)$ Key: CPC (100:0) $\rightarrow$ cassava based prawn cracker (control); CPC $(90: 10) \rightarrow$ cassava based prawn cracker; CPC (80:20) $\rightarrow$ cassava based prawn cracker; PPC (100:0) - Pink fleshed based prawn cracker (control); PPC (90:10) $\rightarrow$ Pink fleshed based prawn cracker; PPC (80:20) $\rightarrow$ Pink fleshed based prawn cracker; OPC (100:0) $\rightarrow$ Orange fleshed based prawn cracker (control); OPC (90:10) $\rightarrow$ Orange fleshed based prawn cracker; OPC (80:20) $\rightarrow$ Orange fleshed based prawn cracker; - $\rightarrow$ Not detected.

fleshed sweet potato starch. There were significant differences $(p<0.05)$ in the vitamin content of the samples studied. The vitamin content of the prawn crackers is shown in Table 6. Carotene, a precursor of Vitamin $A$, of the prawn cracker ranged from 113 to $128 \mathrm{mg} / 100 \mathrm{~g}$. The levels of vitamin A in the controls were $113.23 \mathrm{mg}$ /100 $\mathrm{g}$ for cassava based prawn cracker, 120.43 mg / $100 \mathrm{~g}$ for pink fleshed based prawn cracker and $123.25 \mathrm{mg} / 100 \mathrm{~g}$ for orange fleshed based prawn cracker. They differed $(p<0.05)$ significantly from the values exhibited by the other samples. The recommended daily allowance (RDA) for vitamin A is $900 \mu \mathrm{g}$ (men) and $900 \mu \mathrm{g}$ (women) .The level of vitamin in the samples suggest that consumption of large quantities of the prawn cracker or combining it with other dietary sources is needed to meet the daily requirement. Vitamin $A$ is an antioxidant and also plays a major role in vision. It serves as element of immune system whose functions are influenced by vitamin $A$. In vitamin A deficiency, both cell mediated and antibody -mediated immunity responses are depressed. 
The values for vitamin $B_{1}$ ranged from 0.05 to $0.07 \mathrm{mg}$ $/ 100 \mathrm{~g}$ with orange fleshed based prawn cracker (90:10) having the highest score and cassava based prawn cracker (100:0), cassava based prawn cracker (90:10), pink fleshed based prawn cracker (100:0), pink fleshed based prawn cracker (80:20), orange fleshed based prawn cracker (100:0) and orange fleshed based prawn cracker (80:20) having the lowest score. The daily recommended value for vitamin $B_{1}$ is $1.5 \mathrm{mg}$ (men) and $1.2 \mathrm{mg}$ (women). In other words, to meet the required daily intake means consumption of large quantities of the prawn cracker combining it with other dietary sources is needed to meet the recommended daily requirement. It serves as part of enzymes needed for energy metabolism; important for nerve functioning.

Vitamin $B_{3}$ values were 0.04 to $0.87 \mathrm{mg} / 100 \mathrm{~g}$ with tapioca based prawn cracker (80:20) having the highest score and orange fleshed based prawn cracker (100:0) (Control) are having the lowest score. The daily recommended allowance for vitamin $B_{3}$ as recommended by Food and Nutrition Board (1989). The levels of vitamin in the samples suggest that consumption of large quantities of the prawn cracker or combining it with other dietary sources is needed to meet the daily requirement. It serves as an integral part of enzymes needed for energy metabolism; for nervous system, digestive system and for healthy skin growth.

The values for vitamin $B_{6}$ were between 0.07 to 0.71 $\mathrm{mg} / 100 \mathrm{~g}$ with cassava based prawn cracker (80:20) having the highest value and cassava based prawn cracker (100:0) the lowest value. The daily recommended allowance (RDA) for vitamin $\mathrm{B}_{6}$ is $2 \mathrm{mg}$ (men) and $1.7 \mathrm{mg}$ (women) as recommended by Food and Nutrition Board (1989). The levels of vitamin in the samples suggest that consumption of large quantities of the prawn cracker or combining it with other dietary sources is needed to meet the daily requirement. It forms part of an enzyme needed for protein metabolism. It aids the formation of red blood cells.

The vitamin $B_{12}$ content of prawn crackers samples ranged were between 0.0019 to $0.0038 \mathrm{mg} / 100 \mathrm{~g}$. Orange fleshed prawn cracker $(90: 10)$ had the highest value while orange fleshed prawn cracker (100:0) had the lowest value. The daily recommended allowance for vitamin $\mathrm{B}_{12}$ as recommended by Food and Nutrition Board (1989) is (RDA) for vitamin $B_{12}$ is $6 \mu \mathrm{g}$ (men) and $2.4 \mathrm{\mu g}$ (women). The levels of vitamin in the samples suggest that consumption of large quantities of the prawn cracker or combining it with other dietary sources is needed to meet the daily requirement. It functions as part of an enzyme needed for making new cells (important to nerve function).

The level of vitamin $C$ was only seen in the cassava based samples cassava based prawn cracker (100:0), cassava based prawn cracker (80:20) and cassava based prawn cracker $(90: 10)$. The processing treatments given to the samples caused significant $(p<0.05)$ loss in the vitamin $C$ content of the prawn crackers. The loss in vitamin $C$ during processing agrees with earlier report by Oboh and Akindahunsi (2004). They reported that various conventional food processing methods caused a significant $(p<0.05)$ decrease in the vitamin $C$ content. This loss in vitamin $C$ during processing could be attributed to the fact that vitamin $C$ is very soluble in water and not stable at high temperature (Nagy and Smooth, 1977). The minimal amount of vitamin $C$ in the prawn cracker might be attributed to the high temperature used during frying. The daily recommended value for vitamin $\mathrm{C}$ as recommended by Food and Nutrition Board (1989) is $60 \mathrm{mg}$ (men) and $90 \mathrm{mg}$ (women). Vitamin C acts as an antioxidant in the blood and other body fluids. It regenerates the active antioxidant form of vitamin $E$ and enhances non-haem iron absorption by keeping iron in its more readily absorbed form (Grosvenor and Smolin, 2002). The daily recommended daily allowance for vitamin $\mathrm{E}$ is $30 \mathrm{I} . \mathrm{U}$ (men) and $15 \mathrm{I} . \mathrm{U}$ (women) as recommended by Food and Nutrition Board (1989). It also helps in binding of cells together and quick healing of wounds and cuts and fights mouth infection.

The vitamin $\mathrm{E}$ content of prawn crackers were between 0.15 to $0.38 \mathrm{mg} / 100 \mathrm{~g}$. Orange fleshed based prawn cracker $(80: 20)$ had the highest value cassava based prawn cracker while (100:0) and orange fleshed based prawn cracker (100:0) had the lowest value. These showed significant decrease in relation to the control. The level of vitamin $E(0.15 \mathrm{mg} / 100 \mathrm{~g})$ in the control differed significantly $(p<0.05)$ from the values obtained from the other samples. Vitamin E, as a powerful antioxidant, helps to protect cells from damage by free radicals (Wardlaw and Kessel, 2002). It is also important in maintaining the integrity of the red blood cells and cells of the immune system (Grosvenor and Smolin, 2002). It has also been shown that vitamin $E$ reduces the synthesis of molecules that cause cells to stick to the lining of blood vessels and to increase the synthesis of enzymes needed for the reduction of blood clot formation (Steiner, 1999; Emmert and Kirchmer, 1999). It is also essential for absorption of iron and slowing of the ageing process. Generally, the vitamin content of the prawn crackers were very low compared to their availability in its natural form. However, the decrease may be due to high temperature of frying during the final processing (Huda, 2007).

\section{Mineral composition of prawn cracker produced from cassava, pink and orange fleshed sweet potato starch}

Table 7 shows the mineral content of prawn cracker blends from cassava, pink and orange fleshed sweet potato starch. The mineral content of the fried prawn crackers are shown in Table 7 . The sodium values were 
Table 9. Sensory score of prawn crackers from blends of cassava, pink and orange fleshed sweet potato starch

\begin{tabular}{|c|c|c|c|c|c|c|c|c|}
\hline Samples & Colour & Flavour & Texture & Taste & Aftertaste & Mouth feel & Crispiness & $\begin{array}{l}\text { Overall } \\
\text { acceptability }\end{array}$ \\
\hline CPC(100\%) & $7.55^{\mathrm{a}} \pm 1.95$ & $6.75^{\mathrm{a}} \pm 2.19$ & $6.20^{\mathrm{ab}} \pm 1.8$ & $6.90^{\mathrm{ab}} \pm 1.97$ & $7.00^{\mathrm{a}} \pm 1.74$ & $6.40^{\mathrm{a}} \pm 2.60$ & $7.40^{\mathrm{a}} \pm 1.39$ & $6.80^{a} \pm 2.04$ \\
\hline CPC(90:10) & $6.60^{\mathrm{ab}} \pm 1.66$ & $5.90^{\mathrm{ab}} \pm 1.83$ & $4.85^{\mathrm{cd}} \pm 2.23$ & $5.80^{\mathrm{b}} \pm 1.32$ & $5.50^{\mathrm{bc}} \pm 2.03$ & $5.75^{\mathrm{ab}} \pm 1.91$ & $5.75^{\mathrm{bc}} \pm 1.71$ & $5.70^{\mathrm{a}} \pm 1.38$ \\
\hline $\operatorname{CPC}(80: 20)$ & $6.20^{\mathrm{ab}} \pm 1.88$ & $5.00^{\mathrm{cd}} \pm 2.63$ & $5.75^{\mathrm{bc}} \pm 1.94$ & $4.10^{c} \pm 2.31$ & $5.00^{\mathrm{bc}} \pm 1.77$ & $5.90^{\mathrm{b}} \pm 1.65$ & $6.10^{\mathrm{bc}} \pm 1.86$ & $5.70^{\mathrm{a}} \pm 2.02$ \\
\hline PPC (100\%) & $7.05^{\mathrm{ab}} \pm 1.09$ & $5.55^{\mathrm{bc}} \pm 2.01$ & $5.45^{\mathrm{bc}} \pm 1.93$ & $5.95^{\mathrm{b}} \pm 1.79$ & $5.55^{\mathrm{bc}} \pm 2.13$ & $5.90^{\mathrm{ab}} \pm 1.80$ & $5.35^{\mathrm{c}} \pm 1.72$ & $5.70^{\mathrm{a}} \pm 1.38$ \\
\hline PPC (90:10) & $4.20^{\mathrm{C}} \pm 2.56$ & $4.40^{\mathrm{d}} \pm 2.16$ & $4.60^{\mathrm{cd}} \pm 1.98$ & $3.80^{\mathrm{C}} \pm 2.04$ & $4.50^{C} \pm 2.18$ & $4.80^{\mathrm{b}} \pm 1.79$ & $4.15^{\mathrm{d}} \pm 2.13$ & $4.25^{\mathrm{b}} \pm 2.12$ \\
\hline PPC (80:20) & $4.45^{\mathrm{C}} \pm 2.37$ & $4.35^{\mathrm{d}} \pm 1.98$ & $4.35^{\mathrm{d}} \pm 1.30$ & $4.05^{\mathrm{c}} \pm 2.18$ & $4.80^{\mathrm{cd}} \pm 1.76$ & $4.85^{\mathrm{b}} \pm 1.81$ & $3.95^{\mathrm{d}} \pm 1.43$ & $5.60^{\mathrm{a}} \pm 2.06$ \\
\hline OPC $(100 \%)$ & $4.85^{\mathrm{C}} \pm 1.87$ & $5.75^{\mathrm{cd}} \pm 2.09$ & $5.10^{\mathrm{cd}} \pm 2.14$ & $6.40^{\mathrm{ab}} \pm 2.21$ & $5.60^{\mathrm{bc}} \pm 2.28$ & $6.25^{\mathrm{a}} \pm 1.68$ & $5.85^{\mathrm{bc}} \pm 1.66$ & $5.90^{\mathrm{a}} \pm 1.88$ \\
\hline OPC $(90: 10)$ & $6.95^{\mathrm{ab}} \pm 1.23$ & $7.05^{\mathrm{ab}} \pm 1.50$ & $7.00^{a} \pm 1.12$ & $7.40^{a} \pm 0.868$ & $7.15^{\mathrm{a}} \pm 2.18$ & $6.80^{\mathrm{a}} \pm 1.93$ & $6.65^{\mathrm{ab}} \pm 1.63$ & $6.95^{\mathrm{a}} \pm 1.76$ \\
\hline OPC $(80: 20)$ & $6.35^{\mathrm{ab}} \pm 1.42$ & $6.70^{\mathrm{ab}} \pm 1.41$ & $6.70^{\mathrm{ab}} \pm 1.41$ & $6.10^{\mathrm{b}} \pm 1.68$ & $6.20^{\mathrm{ab}} \pm 2.44$ & $6.10^{b} \pm 1.68$ & $5.95^{\mathrm{bc}} 2.13$ & $6.10^{\mathrm{a}} \pm 2.26$ \\
\hline
\end{tabular}

Values are means \pm standard deviation of duplicate determinations. Values with the same superscript within a column were not significantly different $(p>0.05)$

Key: CPC (100:0) $\rightarrow$ cassava based prawn cracker (control); CPC (90:10) $\rightarrow$ cassava based prawn cracker; CPC (80:20) $\rightarrow$ cassava based prawn cracker; PPC (100:0) - Pink fleshed based prawn cracker (control); PPC (90:10) $\rightarrow$ Pink fleshed based prawn cracker; PPC (80:20) $\rightarrow$ Pink fleshed based prawn cracker; OPC (100:0) $\rightarrow$ Orange fleshed based prawn cracker (control); OPC (90:10) $\rightarrow$ Orange fleshed based prawn cracker; OPC (80:20) $\rightarrow$ Orange fleshed based prawn cracker.

between 13.51 to $117 \mathrm{mg} / 100 \mathrm{~g}$ with orange fleshed based prawn cracker $(80: 20)$ had the highest value while cassava based prawn cracker (100:0) had the lowest value. The addition of table salt and monosodium glutamate during the manufacturing process probably contributed to the sodium content in the fish crackers. The recommended daily allowance RDA for sodium is $2400 \mathrm{mg} \mathrm{(men)}$ and $2400 \mathrm{mg}$ (women) as recommended by Food and Nutrition Board (1989). The level of minerals in the prawn crackers suggests large quantities of the prawn cracker or combining it with other dietary sources is needed to meet the recommended daily allowance. It is a very common electrolyte; (in general not found in dietary supplements, despite being needed in large quantities) because the ion is very common in food typically as sodium chloride or common salt. Excessive consumption can deplete calcium and magnesium leading to high blood pressure and osteoporosis.

The calcium content ranged from 15.56 to 29.92 $\mathrm{mg} / 100 \mathrm{~g}$ with orange fleshed based prawn cracker sample (100:0) had the highest value while tapioca based prawn cracker (100:0) had the lowest value. The recommended daily allowance RDA for calcium is $1000 \mathrm{mg}$ (men) and $1300 \mathrm{mg}$ (women) as recommended by Food and Nutrition Board (1989). However, the level of minerals in the samples suggest that consumption of large quantities of the prawn cracker or combining it with other dietary sources is needed to meet the recommended daily allowance Calcium functions as a constituent of bones and teeth. It also regulates the nerve and muscles function. Calcium activates the conversion of prothrombin to thrombin, takes part in milk clotting and plays a vital role in enzyme activation.

The magnesium content were 20.23 to 23.58 $\mathrm{mg} / 100 \mathrm{~g}$ with orange fleshed based prawn cracker (100:0) had the highest value and pink fleshed based prawn cracker (90:10) had the lowest value. The recommended daily allowance RDA for magnesium is RDA of $400 \mathrm{mg}$ (men) and $420 \mathrm{mg}$ (women) as recommended by Food and Nutrition Board (1989). Magnesium is required for processing ATP and related reactions (builds bones, causes strong peristalsis, increases flexibility and alkalinity).

The iron content of the prawn cracker ranged from 0.22 to $0.71 \mathrm{mg} / 100 \mathrm{~g}$ with cassava based prawn cracker $(80: 20)$ had the highest value while pink fleshed based prawn cracker (90:10) had the lowest value. The recommended daily allowance (RDA) for iron is $18 \mathrm{mg}$ (men) and $18 \mathrm{mg}$ (women) as recommended by Food and Nutrition Board (1989). However, the level of minerals in the samples suggest that consumption of large quantities of the prawn cracker or combining it with other dietary sources is needed to meet the recommended daily allowance. According to Pelletier et al. (1993), iron is essential for the production of hemoglobin which helps to deliver oxygen from lung to body tissues, transport electrons in cells, and synthesize enzymes that are required to utilize oxygen for the production of cellular energy. Iron deficiency is the commonest and most widespread micronutrient deficiency in the world and affects over one million people in tropical and sub-tropical zones, (ACC/SCN, 1992). 
Nwaoha and Itoje, 081

Table 10. Mold count (cfu/g) of fried prawn cracker during one month storage period

\begin{tabular}{lllll}
\hline Samples & Week 1 & Week 2 & Week 3 & Week 4 \\
\hline CPC $(100: 0)$ & - & $1.05 \times 10^{2}$ & - & - \\
CPC $(90: 10)$ & - & - & $1.05 \times 10^{3}$ & $2.05 \times 10^{4}$ \\
CPC $(80: 20)$ & - & - & - & - \\
PPC $(100: 0)$ & - & $9.50 \times 10^{2}$ & $1.55 \times 10^{3}$ & $2.55 \times 10^{4}$ \\
PPC $(90: 10)$ & - & - & $9.50 \times 10^{3}$ & $1.05 \times 10^{4}$ \\
PPC $(80: 20)$ & - & - & $1.05 \times 10^{3}$ & $9.50 \times 10^{4}$ \\
OPC(100:0) & $1.05 \times 10$ & - & $2.05 \times 10^{3}$ & $1.95 \times 10^{4}$ \\
OPC(90:10) & - & - & $1.05 \times 10^{3}$ & $1.05 \times 10^{4}$ \\
OPC(80:20) & - & - & $1.05 \times 10^{3}$ & $1.05 \times 10^{4}$ \\
\hline
\end{tabular}

Values are means \pm standard deviation of duplicate determinations. Values with the same superscript within a column were not significantly different $(p>0.05)$

Key: CPC $(100: 0) \rightarrow$ cassava based prawn cracker (control); CPC (90:10) $\rightarrow$ Cassava based prawn cracker; CPC (80:20) $\rightarrow$ Cassava based prawn cracker; PPC (100:0) - Pink fleshed based prawn cracker (control); PPC (90:10) $\rightarrow$ Pink fleshed based prawn cracker; PPC (80:20) $\rightarrow$ Pink fleshed based prawn cracker; OPC (100:0) $\rightarrow$ Orange fleshed based prawn cracker (control); OPC $(90: 10) \rightarrow$ Orange fleshed based prawn cracker; OPC (80:20) $\rightarrow$ Orange fleshed based prawn cracker; - $\rightarrow$ no growth

The copper content of the prawn cracker ranged from 0.11 to $0.48 \mathrm{mg} / 100 \mathrm{~g}$ with orange fleshed based prawn cracker $(80: 20)$ had the highest value while cassava based prawn cracker $(80: 20)$ had the lowest value and pink fleshed based prawn cracker (80:20). The recommended daily allowance (RDA) for copper is $2 \mathrm{mg}$ (men) and $900 \mu \mathrm{g}$ (women) as recommended by Food and Nutrition Board (1989). However, the level of minerals in the samples suggests that consumption of large quantities of the prawn cracker or combining it with other dietary sources is needed to meet the recommended daily allowance. Copper is involved in many enzyme processes including cytochrome C oxidase. It is necessary for photosynthesis and also involved in the manufacture of lignin.

The zinc content range from 0.15 to $0.44 \mathrm{mg} / 100 \mathrm{~g}$ with orange fleshed based prawn cracker (80:20) having the highest value while cassava based prawn cracker (80:20) had the lowest value. The recommended daily allowance (RDA) for zinc is $15 \mathrm{mg}$ (men) and $11 \mathrm{mg}$ (women) as recommended by Food and Nutrition Board (1989). However, the levels of minerals in the samples suggest that consumption of large quantities of the prawn cracker or combining it with other dietary sources is needed to meet the recommended daily allowance. Zinc is an important component of carotenoid which forms a non-enzymatic covalent bonding with chlorophyll (Adeyemi et al. 2009).

The selenium content of the prawn cracker ranged from 0.66 to $4.77 \mathrm{mg} / 100 \mathrm{~g}$ with orange fleshed based prawn cracker $(80: 20)$ had the highest value while orange fleshed based prawn cracker (100:0) had the lowest value of $4.77 \mathrm{mg} / 100 \mathrm{~g}$. The recommended daily allowance (RDA) for selenium is $70 \mu \mathrm{g}$ (men) and $55 \mu \mathrm{g}$ (women) as recommended by Food and Nutrition Board (1989). The level of minerals in the samples is suggestive that consumption of large quantities of the prawn cracker or combining it with other dietary sources is needed to meet the recommended daily allowance. Selenium is required for peroxidase (antioxidant proteins).

Anti-nutritional composition of prawn crackers produced from cassava, pink and orange fleshed sweet potato starch.

Table 8 shows the anti- nutritional factors of prawn cracker from blends of cassava, pink and orange fleshed sweet potato starch. From Table 8, the tannin content of the prawn crackers ranged from 0.11 to $0.18 \mathrm{mg} / \mathrm{g}$, the trypsin inhibitor content ranged from 0.11 to $0.27 \mathrm{Tiu} / \mathrm{g}$. There was decrease in tannins and trypsin inhibitor content with reduction in the starch content for the potato based prawn crackers but it was not observed in the cassava based prawn cracker. The cyanide content in cassava based samples ranged from 0.40 to $1.02 \mathrm{mg} / \mathrm{g}$, pink fleshed based prawn cracker ranged from 1.00 to $1.02 \mathrm{mg} / \mathrm{g}$ and that of orange fleshed based prawn crackers 0.89 to $100 \mathrm{mg} / \mathrm{g}$. Cyanide decreased with reduction in starch ratio. It was observed that the values for the antinutritional factors for all the prawn crackers were low and this reduction was expected as soaking helped in the removal of the soluble anti-nutrients. This result was in agreement with the report of Philips and Abbey (1989), that steeping hydrates the tuber and induces the leaching out of water soluble anti-nutrients such as glycoside, alkaloids, phytates, oligosaccharides and tannins. As recommended by Egbe and Akinyele (1990), the application of heat on foods for longer period helps to reduce drastically anti-nutrients in foods. It has been deduced that from the preprocessing treatment given (soaking, steaming/ boiling and frying) to the prawn cracker during the production process was adequate in the removal of most of this anti-nutrients. All the antinutrients were found below or within the permissible level (1\%), showing that the samples were fit for consumption. Thus, the significant reduction of these anti-nutrients as observed in this study was indicative of improved safety, hence is desirable. 


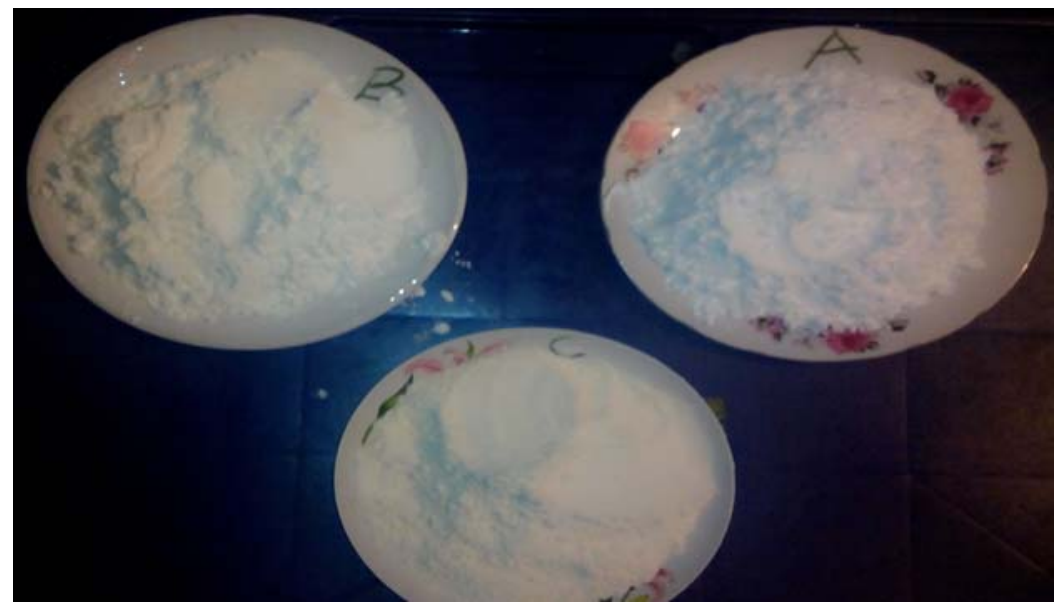

Plate 1. Starches extracted from cassava, pink and orange fleshed sweet potatoes Where $\mathrm{A}=$ Starch from cassava; $\mathrm{B}=$ Starch from pink fleshed sweet potatoes; $\mathrm{C}=$ orange fleshed sweet potatoes.

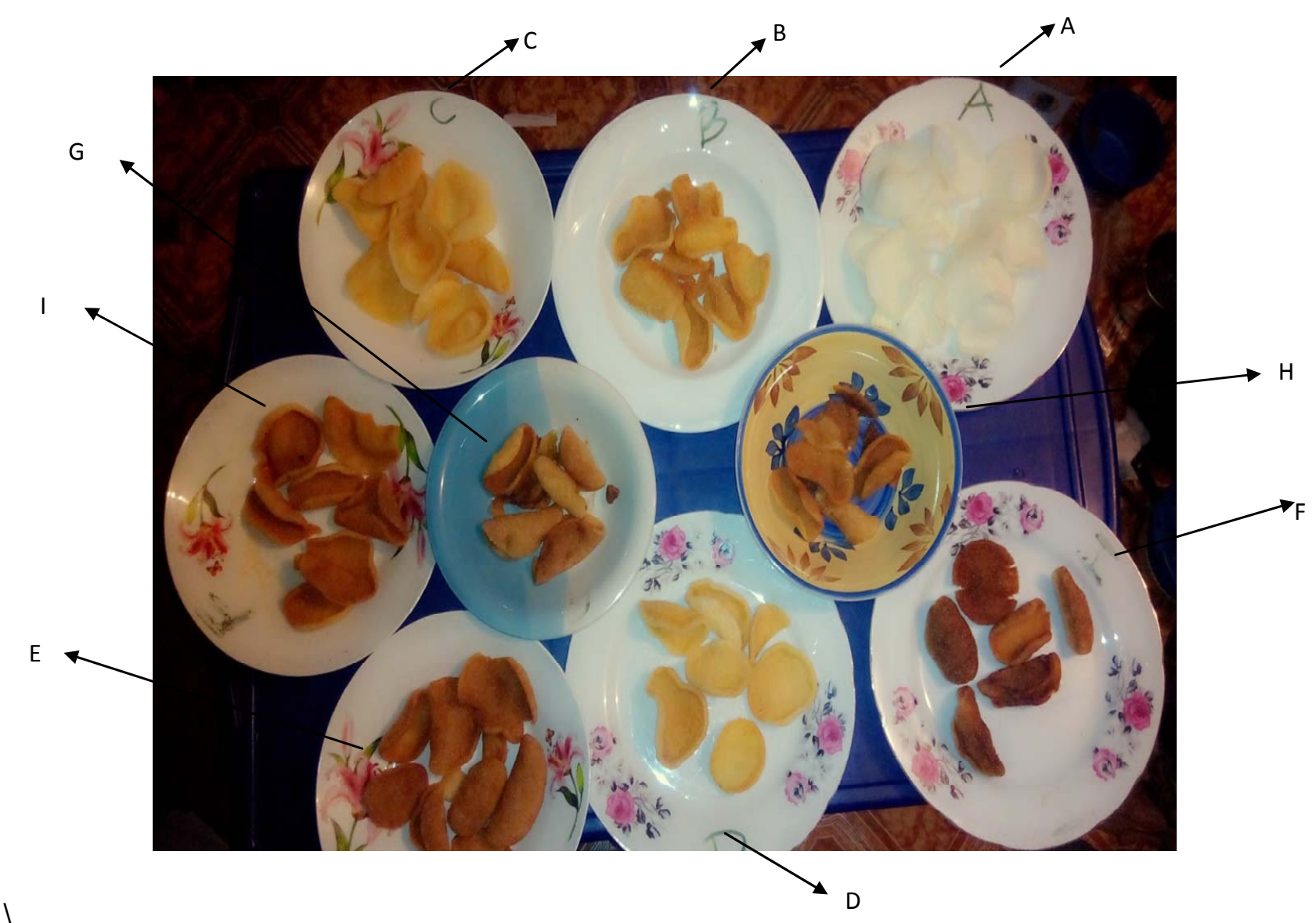

Plate 2. Plates containing fried prawn crackers

Key: A (100:0) $\rightarrow$ Cassava based prawn cracker (control); B (80:20) $\rightarrow$ Cassava based prawn cracker; C $(90: 10) \rightarrow$ Cassava based prawn cracker; D (100:0) - Pink fleshed based prawn cracker (control); E (80:20) $\rightarrow$ Pink fleshed based prawn cracker; F $(90: 10) \rightarrow$ Pink fleshed based prawn cracker; G $(100: 0) \rightarrow$ Orange fleshed based prawn cracker (control); H $(80: 20) \rightarrow$ Orange fleshed based prawn cracker; I $(90: 10) \rightarrow$ Orange fleshed based prawn cracker. 
Generally, anti-nutrients are considered toxic. For instance, tannins may form insoluble complexes with proteins thereby decreasing the digestibility of proteins (Uzoechina, 2007). Tannins may decrease protein quality by decreasing digestibility and palatability, damaging the intestinal tract, and enhancing carcinogenesis (Makkar and Becker, 1996). Furthermore, tannins could impair iron availability (Svanberg et al., 1993; UdayasakharaRao, 1995) whereas phytates up to $1 \%$ could interfere with mineral bioavailability (Anigo et al., 2009), including iron and calcium (Alonso et al., 2001). Various authors have suggested different minimal levels of toxicity for cassava. Rosling (1987) was of the opinion that an intake of over $20 \mathrm{mg} / \mathrm{g}$ of cassava could be toxic while Bolhuis (1954) set the toxic level at an intake of $50-60 \mathrm{mg}$ daily for a European adult. The only available information on the dietary intake of polyphenols are $1 \mathrm{~g} /$ day (USDA), 23 $\mathrm{mg} /$ day (Dutch) and $28 \mathrm{mg} /$ day (Demark) accordingly to Santosh et al (1998).

Sensory scores of prawn crackers produced from cassava, pink and orange fleshed sweet potato starch.Table 9 shows the sensory scores of prawn crackers from blends of cassava, pink and orange fleshed sweet potato starches (Plate 2). There were significant differences $(p>0.05)$ in terms of colour, texture, flavor, taste, aftertaste and mouth feel (Table 9). However, there were no significant $(p<0.05)$ differences in terms of overall acceptability. The colour of the prawn crackers ranged between $4.20-7.55 \%$ (Table 9). All the colour values showed significant $(p<0.05)$ differences between each fried prawn cracker.

However, increasing the prawn ratio or decreasing the tapioca starch ratio contributed to a darker product. Cassava based prawn cracker samples (100:0) and pink fleshed based prawn cracker $(100: 0)$ exhibited a bright and clear product. The lighter product which resulted may be related to the cassava starch. Similar reports where obtained by other researchers where the panelists preferred the lighter colour of the prawn crackers ( $\mathrm{Yu}$, 1991a; Huda et al., 2000; 2001; 2009).

Cassava flour is a white colored product while prawn contains some pigments which contribute to the colour of the product. A variety of nitrogenous compounds such as myoglobin, hemoglobin and hemocyanins contribute to the colour of the prawn (Haard et al., 1994). The colour of prawn varied depending on the specie. Peranginangin et al. (1997) found that fish crackers made from snapper fish were shown to be the darkest as compared to the pike conger and the feather back fish. The frying process would result in the loss of the lighter colour of the fried product. A frying process with a high temperature contributed to the denaturation and oxidation of fish protein which led to the darker colour of the product. The formation of coloured compounds related with involvements of water released from amino acid and in Maillard-type reactions (Sikorski and Pan, 1994). Ngadi et al. (2007) stated the decrease in the fried food sample may be attributed to Maillard browning and caramelizing at a high frying temperature. The rate of Maillard reaction depends on its chemical environment such as the chemical composition of food, water activity, $\mathrm{pH}$ and the reaction temperature.

Huda et al. (2007) reported that commercial fish crackers showed a wide range of linear expansion which is within $38-145 \%$. Mohamed et al. (1988) found a similar trend and this is because more oil was trapped on the surface layer of the bigger air "cells" when expansion increased. Huda et al. (2000; 2001) as well as King (2002) reported that as a result of oil absorption, the fat content of fried fish crackers is higher in the sample with the higher linear expansion compared to the sample with a lower linear expansion. As shown in Table 8, the more the degree of the expansion of the crackers, the more air cells would form and the more oil was trapped, consequently, the higher the degree of oil absorption. The hardness of fried crackers increased with the decrease in linear expansion. As previously mentioned, the lower degree of linear expansion is related to the increase of fish protein. Cheow et al. (1999) studied the microstructure of fish crackers and found that poorlyexpanded fish crackers contained large aggregates of fish protein. This prevented the starch from expanding in hot cooking oil and made the filaments more dense and thick and the final result was the increase in the hardness value. Hardness was determined by sensory evaluation in terms of crispiness which is an opposite term for hardness. Low hardness was shown as a high crispiness score and consumers prefer fish crackers with a high crispiness score. Peranginangin et al. (1996) found that increasing linear expansion would increase the crispiness score of fish crackers which means that the product has lower hardness value. Similar results were also reported by Yu (1991b).

\section{Microbial count of prawn crackers}

Table 10 shows Mold count (cfu/g) of fried prawn cracker during one month storage period.

Mold growth (cfu/g) of prawn crackers in room (28 \pm 2 ${ }^{\circ} \mathrm{C}$ ) gradually increased during the storage period (Table 10). At week one, mold growth was observed in orange fleshed based prawn cracker sample (100:0) $1.05 \times 10$ cfu/g. At week two, mold growth was observed in cassava based prawn cracker (100:0) $1.02 \times 10 \mathrm{cfu} / \mathrm{g}$ and pink fleshed based prawn cracker (100:0) $9.50 \times 10^{2}$ $\mathrm{cfu} / \mathrm{g}$. It increased with the progress of storage time. At week three, cassava based prawn cracker samples (90:10), orange fleshed based prawn cracker (80:20), and orange fleshed based prawn cracker (90:10) had $1.05 \times 10^{3} \mathrm{cfu} / \mathrm{g}$. On the other hand, in the case of cassava based prawn cracker (80:10) storage no remarkable change was observed. This was unacceptable for consumption. Therefore the results showed that the products made with $10 \%$ shrimp shell 
powder had an acceptable bacterial for up to 30 days. The reason for the growth according to Neeraj and Sharma (2007) may be attributed to available nutrients, its low $\mathrm{pH}$, and leakage in the packaging material.

\section{CONCLUSION}

The results of this study showed that blending of prawn and starch affected the quality of formulated prawn crackers. Increasing the prawn in the formulation increased the amount of protein in the prawn cracker, reduced the expansion rate, increased oil absorption and gave low crispy products. The hardness of the products increased with increase of prawn content. The vitamin, mineral and antinutritional content were generally low. The quality of the prawn cracker with blends for orange fleshed sweet potato (90:10) produced high expansion, low bulk density and hard textured product. The colour of the product was light brown. This formulation also resulted in crackers with big air cells and thin cell walls. The product had high crispiness and was highly accepted by the pane lists. During storage there was mold growth as storage time progressed, therefore the product is most suited when consumed few hours after production. Based on the findings, it was recommended that the utilization of the prawn waste could minimize the cost of waste disposal that would realize substantial savings. The prawn crackers could be a remarkable source of high quality protein, because of its abundance and cost. Value added products like protein fortified prawn crackers could be prepared from under-utilized shrimp shell wastes. Prawn crackers could be served as a high quality protein source for people suffering from malnutrition.

\section{REFERENCES}

ACC / SCN [Administrative Committee on Co-ordination / Subcommittee on Nutrition] (1992). Highlights of the World Nutrition Situation, Food prices and nutrition, food security and nutrition- Long-term effects of improved childhood nutrition. pp. 1971 - 1973.

Adebowale, KO, Olu-Owolabi BI, Olayinka OO, Olayide OS (2005). Effect of heat moist treatment and annealing on the physicochemical properties of red sorghum. African J. Biotechnology, 4 (9): $928-933$.

Adeyemi O, Ajayi JO, Olajuyin AM, Oloyede OB, Oladiji AT, Oluba OM, Adeyemi O, Ololade I A,Adebayo, E. A. (2009). Toxicological evaluation of the effect of water contaminated with lead, phenol and benzene on liver, kidney and colon of Albino rats. Food and Chemical Toxicology, 47: 885-887. Available online at: http://www.elsevier.com/locate/foodchemtox).

Anigo IA, Ameh DA, Ibrahim S, Danbauchi, SS (2009). Nutrient composition of commonly used complimentary foods in north western Nigeria. African J. for Biotech. 8 (17): 4211 - 4216.

Anon (2012a). History of prawn crackers. Cited online. www.wikipedia Accessed on $26^{\text {th }}$ March, 2012.

Anon (2012b). How to make prawn crackers. Cited online c/how-tomake-prawn crackers htm. Accessed on $12^{\text {th }}$ April 2012.

AOAC (2010). Official Methods of Analysis, $18^{\text {th }}$ Edition Association of Analytic Chemists, Gaithersburg.

Armtfiled SD, Ismond MA, Murray ED (1985). The fate of antinutritional factors during the preparation of faba bean protein isolate using micellization techniques. Cannista Institute Food Sci. Inno. J. 18:
$137-143$

Beuchat LR (1977). Functional and electrophoretic characteristic of succinylated peanut flour proteins. Agricultural Journal for Food Chemistry, 25: 258 - 261.

Cheow CS Yu SY (1997). Effect of fish protein, salt, sugar and monosodium glutamate on the gelatinization of starch in fish-starch mixtures. Journal of Food Processing and Preservation, 2 (2): 161 177.

Cheow CS, Yu SY, Howell NK, Che-Man Y, Muhammad K (1999). Effect of fish, starch and salt contents on the microstructure and expansion of fish crackers ('keropok'). Journal of the Science of Food and Agriculture, 79: 879 - 885.

Egbe AA, Akinyele IO (1990). Effect of cooking on the anti-nutritional factors of lima beans. (Phaseolus lunatus). Food Chemistry, 35: 81 87.

Emmert DH, Kirchmer JT (1999). The role of vitamin E in prevention of heart disease. Archaeological Family Medical, 8: 537 - 542.

FNB [Food and nutrition board] (1989). Institute - Dietary reference intakes for vitamin $\mathrm{A}$ and $\mathrm{K}$, arsenic, boron, molybdenum, zinc, silicon and nickel. Washington D.C. Standing Committee on Scientific Evaluation of Dietary reference Intake. National Academy Press U.S.A, pp. 28.30.

Grosvenor MB, Smolin LA (2002). Nutrition: From science to life. Harcourt College Publishers, New York, pp. 288 - 371; 404 - 469.

Harrigan WF, McCance MC (1976). Laboratory Methods in Food and Microbiology. 1st edition Academic Press, London, pp. 139 - 150,

Haard NF, Simpson BK, Pan BS (1994). Sarcoplasmic proteins and other nitrogenous compounds. In: Seafood proteins, Sikorski, Z. E., Pan, B. S. and Shahidi, F. (Eds.). Chapman and Hall New York, pp. $13-39$.

Hiu LS (2012). How to make prawn crackers. Cited online videojug corporation limited. Retrieved on $26^{\text {th }}$ March, 2012.

Holloway WD, Argall ME, Jealous WT, Lee JA, Bradbury JH (1989). Organic acids and calcium oxalate in tropical root crops, J. Agric. and Food Chem, 37: 337 - 341.

Huang CC, Lin MC, Wang CCR (2006). Changes in morphological, thermal, and pasting properties of yam (Dioscorea alata) starch during growth. Carbohydrate polymers, 64: $524-531$.

Huda N, Boni I, Noryati I (2009). The effect of different ratios of Dory fish to tapioca flour on the linear expansion, oil absorption, colour and hardness of fish crackers. International Food Research Journal, 16: $159-165$.

Huda N, Aminah A, Babji AS (2000). Physicochemical and sensory characteristic of cracker formulated with research. Cracker "Keropok": A review on factors influencing expansion International Food Research Journal, 18 (3): 855 - 866

Huda N, Aminah A, Babji AS (2001). Substitution of tapioca flour with surimi powder in traditional crackers (keropok palembang). Sixteenth $\left(16^{\text {th }}\right)$ Scientific Conference Nutrition Society of Malaysia, Kuala Lumpur held at $24^{\text {th }}-25^{\text {th }}$ March, 2001.

Huda N, Ismail N, Leng AL Yee CX (2007). Chemical composition, colour and linear expansion properties of commercial fish cracker. 12th Asian Chemical Congress, Kuala Lumpur, $23^{\text {rd }}-25^{\text {th }}$ August, 2007.

Ihekoronye Al Oladunjoye MG (1988). Formulation and physicochemical properties of high-protein food beverage powder based on protein concentration from the Nigerian red skin groundnut (Arachis hypogae) protein concentrates. Journal of Science, Food and Agriculture, 54: 89 - 98.

Ihekoronye Al Ngoddy PO (1985). Integrated Food Science and Technology for the Tropics. Macmillan Publishers Ltd, London.

Kakade NL, Racis JJ, Mcchee JE, Puski C (1995), Determination of trypsin inhibitor activity of soy products: A collaboratory analysis of improved procedure. Cereal Chemistry, 51: 376 - 377.

King MA (2002). Development and sensory acceptability of crackers made from the big-eye fish (Branchydeuterus auritus). Food and Nutrition Bulletin, $23(2): 317-340$

Leach HW, Mccowen LD, Schoch TJ (1959). Structure of the starch granules I- Swelling and solubility patterns of various starches. Cereal Chemistry, 36: 534 - 541.

Makkar HPS, Becker K (1996). Effect of pH, temperature and time on inactivation of tannin and possible implication in detannification studies. J. Agric. and Food Chem, 44: 1291 - 1295. 
different types of flour. Association of South East Asian Nations group of nations in Asian country (ASEAN) Food Journal, 6 (3): $114-116$.

McCurdy SM, Joey P, Wittman G (2009). The importance of food pH in commercial canning operations. Published and distributed in furtherance of the arts of congress of May 8 and June 30, 1914 by University of Idah Extension, the Oregon state, University extension services Washington state university extension and the US Department of Agriculture. pp 1-3.

Mohamed S, Abdullah N, Muthu MK (1988). Physical properties of keropok (fried crisps) in relation to the amylopectin content of starch flour. Journal for Agriculture and Food Chemistry, 49: 369 - 377.

Nagy S, Smooth JM (1977). Temperature and storage effects on percent retention and percent U.S. recommended dietary allowance of vitamin $C$ in canned single-strength orange juice. Journal for Agriculture and Food Chemistry, 25: 135 - 138.

NAS [National Academies of Sciences of the United States] (2005). Dietary reference intakes for energy, carbohydrate, fiber, fat, fatty acids, cholesterol, protein, and amino acids (Macronutrients). Food and Nutrition Board, Institute of Medicine of the National Academies, National Academies Press, Washington, D. C., USA. Available online at

Http://www.nap.edu/catalog.php?record_id=10490.

Neeraj D, Sharma S (2007). Food spoilage, food infections and intoxications caused by microorganism and method of their detection. Guru Jambheshwar University of Science and Technology, United States of America, Revised 25 September 2007. pp 1- 10

Newport Scientific Incorporated (1998). Applications manual for the rapid viscosity analyzer using thermocline for windows. Newport scientific Australia. pp. 2 - 26.

Ngadi M, Li Y, Oluka S (2007). Quality changes in chicken nuggets fried in oils with different degrees of hydrogenation. LWT-Food Science and Technology, 1: 4 - 6.

Obasi, NE Chukwuma, CS (2015). Quality evaluation of cassava crackers made from yellow root cassava (Manihot esculenta). IOSR Journal of Environmental Science, Toxicology and Food Technology (IOSR-JESTFT) 9(5/1): 93 -101. www.iosrjournals.org.

Oboh G, Akindahunsi AA (2004). Change in the ascorbic acid, total phenol and antioxidant activity of some sun dried green leafy vegetables in Nigeria. Nutrition Health, 18: 29 - 36.

Oguntunde AO (1987) Review: Starch modification for food application. Nigerian Food Journal, 5: 102 - 107.

Omodamiro RM, Iwe MO, Ukpabi UJ (2007). Pasting and functional properties of lafun and starch processed from some improved cassava genotypes in Nigeria. Nigerian Food Journal, 25 (2): 122 126.

Onimawo IA, Egbekun MK (1998). Comprehensive Food Science and Nutrition (Revised edition). Ambik publishers, Benin City. pp. 8-10.

Parkinson R (2006). Prawn crackers (Prawn Flavored chips/shrimp chips). Cited online: www.about.com guide. Accessed on $24^{\text {th }}$ February, 2012.

Pasko P, Sajewicz M, Gorinstein S, Zachwieja, Z (2008). Analysis of selected phenolic acids and flavonoids in Amaranthus cruentus and Chenopodium quinoa seeds and sprouts by HPLC. Acta Chromatographica, 4: 661 - 672.

Pearson D (1976). The Chemical Analysis of Foods, $7^{\text {th }}$ Edition, Churchill Livingstone, Edinburgh. pp. 494 - 497.

Peleg N, Hollenbach AM (1983). Interparticle surface affinity and the bulk properties of conditioned powders. Powder Technology, 35: 51 $-62$.

Pelletier DL, Frongillo EA, Habicht JP (1993). Epidemiological evidence for a potentiating effect of malnutrition on child mortality. American Journal Public Health, 83 (8): 1130 - 1133.

Peranginangin R, Fawzya YN, Sugiyono IJ, Muljanah I (1996). Food additives and effect of thickness on fish crackers quality. Proceedings of the seminar on the advances in fish processing technology in Southeast Asia in relationship to quality management.

Marine Fisheries Research Department Southeast Asian Fisheries Development Centre in collaboration with the Government of Japan, Oct $29^{\text {th }}-$ Nov $1^{\text {st }}$, pp. $106-114$.
Peranginangin R, Fawzia YN, Sugiyono IJ, Mulyanah, I. (1997). Food additives and effect of thickeness on fish crackers quality. Marine Fisheries Research Department Southeast Asian Fisheries

Development Centre in collaboration with the Government of Japan, Nov 1st. 1997. pp: $102-108$

Phillips RD, Abbey BW (1989). Composition and flatulence producing potential of commonly eaten Nigeria and American Legumes. Food Chemistry, 33 (4): $271-280$.

Sanni LO, Ikuomola DP, Sanni SA (2001). Effect of length of fermentation and varieties on the qualities of sweet potato gari. Proceedings of 8th triennial Symposium of the International Society for Tropical Root Crops. Africa Branch (ISTRC-AB),. M.O. Akoroda Edition, IITA, Ibadan, Nigeria, 12 -16 November 2001, pp. 208 211.

Santoch K, Richard KO Owusu A (1998). The role of food, agriculture, forestry and fisheries in human nutrition. In: Anti-nutritional factors in food legumes and effects of processing. 4: 5-8.

Sathe SK, Salunkhe D (1981). Isolation, partial characterizations and modification of the great Northern bean (Phaseolus vulgaris L.) starch. Journal of Food Science, 46: 617 - 621.

Sefa-Dedeh S (1989). Effects of particle size on some physico-chemical characteristics of agbelima cassava dough and corn dough. Tropical Science. 29: $21-32$.

Seth M, Rao ES (2008). Food Science: Experiments and Applications. $1^{\text {st }}$ Edition, University of Delhi. CBS Publishers and distributors, India. pp 21 - 31

Shimelis AE, Meaza M, Rakshit S (2006). Physico-chemical properties, pasting behaviours and functional characteristics of flours and starches from improved bean (Phaseolus vulgaris L.) varieties Grown in East Africa. International Council for Large Electric systems (CIGRE) Journal, 8: 1 - 18.

Sikorski ZE, Pan BS (1994). The effect of heat induced changes in nitrogenous constituents on the properties of sea foods (Seafood Proteins). Chapman and Hall, New York. pp. 84 - 98.

Singh N, Singh J, Kaur L, Sodhi NS, Gill BS (2003). Morphological, thermal and rheological properties of starches from different botanical sources. Food Chemistry, 81: 219 -231.

Steele RGD, Torrie JH (1981). Principles and procedures of statistics. A Biometric approach. McGraw-Hill Books Company Incorporated, New York. pp. 12 - 102.

Steiner M (1999). Vitamin E, a modifier of platelet function: Rationale and use cardiovascular and cerebro-vascular disease. Nutrition, 57: $306-309$.

Strasse JR (2012). Potato starch exaction. Cited online. C: /users/hp/downloads/pstarch.htm. Accessed on 12 ${ }^{\text {th }}$ April, 2012.

Svanberg U, Lorri W, Sanbberg AS (1993). Lactic fermentation of nontannin and high-tannin cereals: Effect on in vitro estimation of iron availability and phytate hydrolysis. Journal of Food Science, 58: 408 $-412$.

Tattiyakul JT, Naksriarporn P, Pradipasena P, Miyawaki M (2006). Effect of moisture on hydrothermal modification of yam (dioscorea hispida) Starch/Starke, 58: 170 - 176.

Tee ES, Noor MI, Azudin MN, Idris K (1997). Nutrient composition of Malaysian foods: 4th Edition. Malaysian Food Composition Database Programme. Institute for Medical Research, Kuala Lumpur.

Tester RF, Morrison WR (1990). Swelling and gelatinization of cereal starches I. Effects of amylopectin, amylose and lipids. Cereal Chemistry, 67: $551-557$.

Udayasakhara-Rao $P(1995)$. Effect of germination on tannin, mineral and trace element composition of groundnut varieties. Journal of the American Oil Chemists Society (JAOCS), 74: 477 - 480.

Uzoechina OB (2007). Evaluation of the effect of processing techniques on the nutrient and anti-nutrient contents of pigeon pea (Cajanus cajan) seed flours. Journal of Food Science, 28: 76 -77.

Wardlaw GM Kessel MW (2002). Perspective in Nutrition (5 $5^{\text {th }}$ edition) McGraw-Hill publishers, New York. pp. 451 - 452.

Yu SY (1991a). Effect of fish: flour ratio on fish crackers 'keropok'. Association of South East Asian Nations group of nations in Asian country (ASEAN) Food Journal, 6 (1): 36 - 37

Yu SY (1991b). Acceptability of fish crackers (keropok) made from 